\title{
اتجاهات وتحديات الواقع الافتراضي في تعليم التصميم المعجاري
}

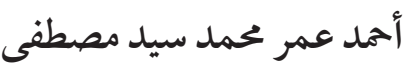

أستاذ مشارك

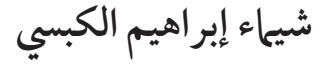

طالب ماجستير

قسم العمارة وعلوم البناء، كلية العمارة والتخطيط، جامعة الملك سعود، المملكة العربية السعودية.

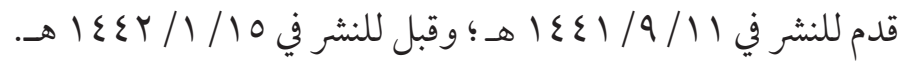

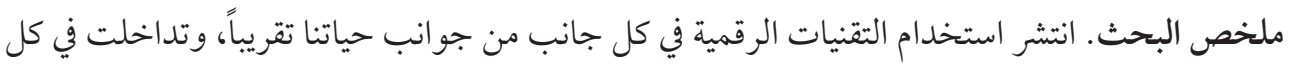

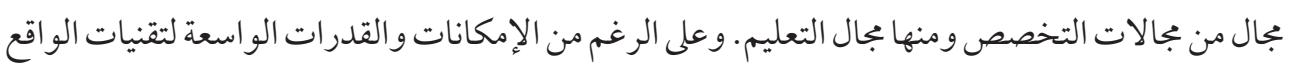

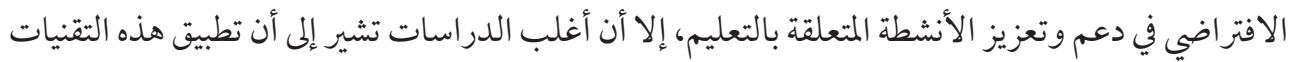

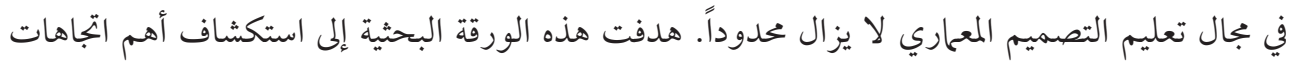

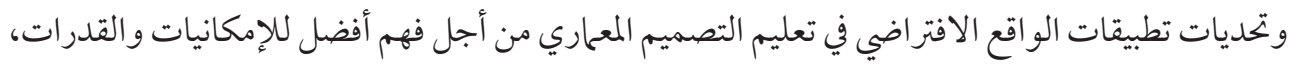

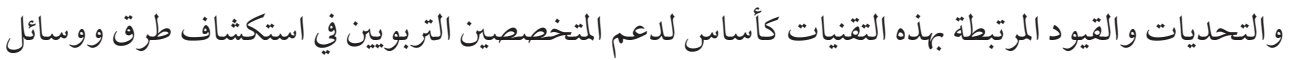

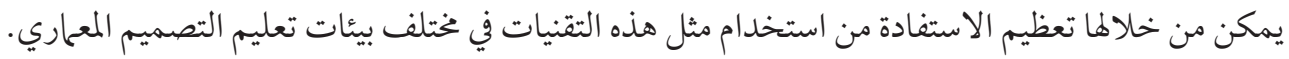

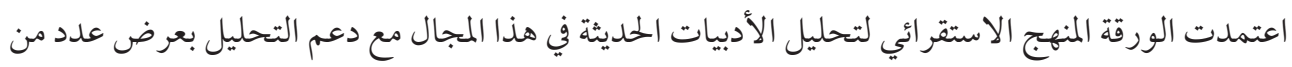

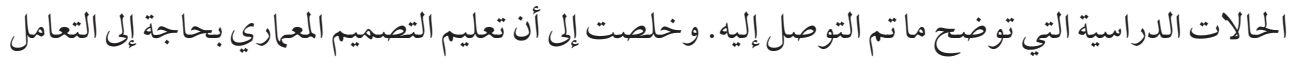

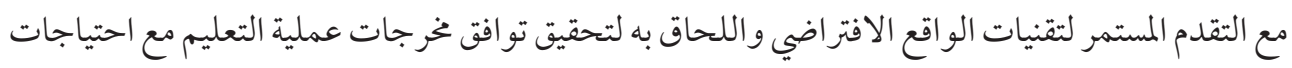

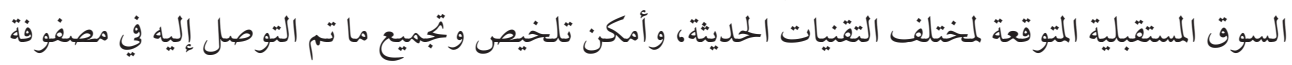

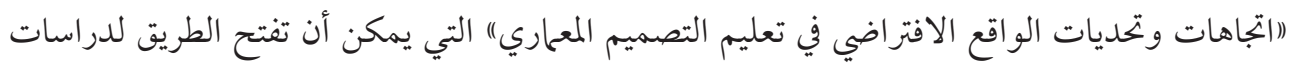

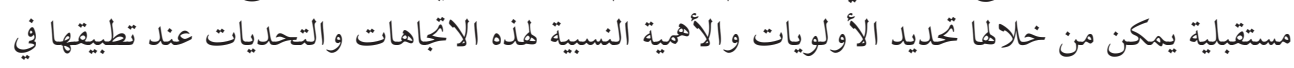
البيئات المختلفة لتعليم التصميم المعماري.

الكلمات المفتاحية: الواقع الافتراضي، تعليم التصميم المعماري، البيئات الافتراضية، الهولوجرام في التعليم

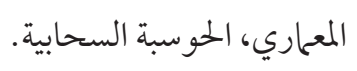


جــالات اسـتخدامها، فقـد اعتـبرت ضمــن إحـــى

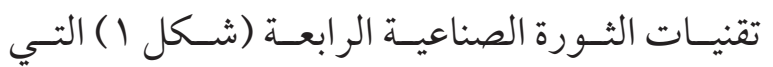

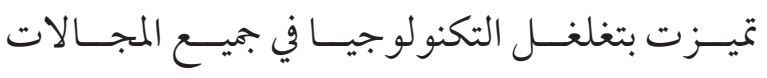

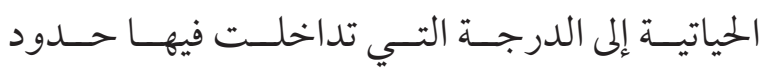

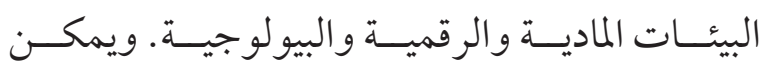

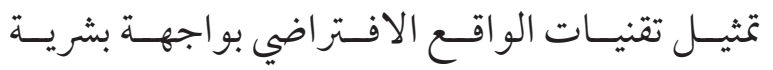

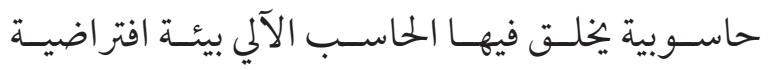

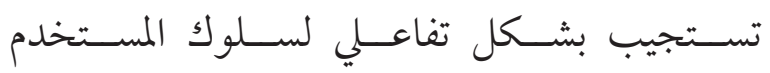
ويتحكــم فيهــا الحاسـبـ بكائنـات أو بيئـات ثلاثيــة

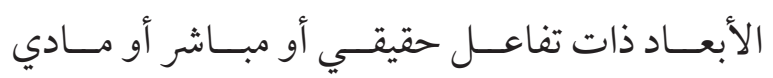

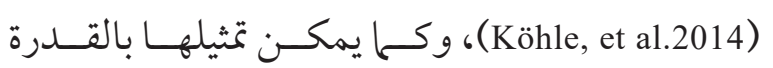
عـلى ححـاكاة الخيــال بالو اقــع عـن طريسـق أجهــزة خصصــة تعمـل عــلى معالجــة البيانـات وإرســاهل لــلأداة المســتخدمة لتكويسـن بيئـات كاملــة يمكــن Sanchez., (التحــك و الرؤيسة والتحكـــم الجزئسي بهـا (et al 2019 . ولتحقيـق الإحسـاس بالو اقعيـة للبيئات

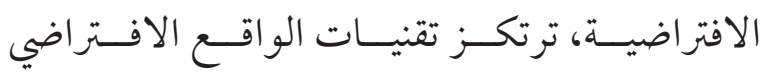

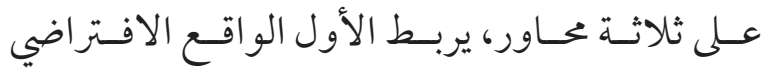

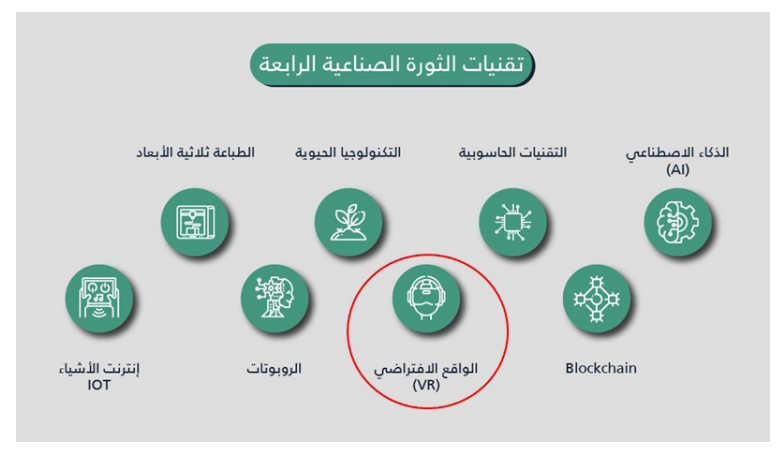

$$
\begin{aligned}
& \text { الشـكل رقــم (1) . تقنيـات الواقـع الافـتراضي إحـــى تقنيـات }
\end{aligned}
$$

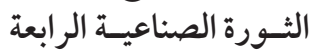

https://blog.sawim.com/transfer-and-localize-technology-from-the-world-to-your-company-and-industry/

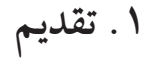

يمثــل التصميــم عمليــة عقليـة منظمــة

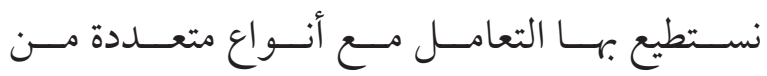

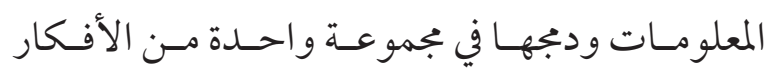

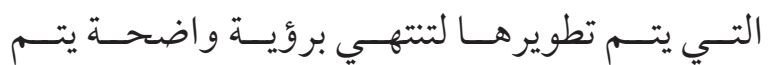

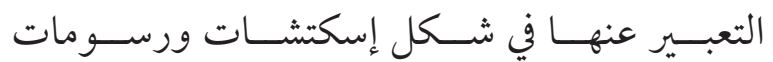
متعـددة الأبعـاد (Pamungkas., et al. 2018) . ويشـغل التصميــم المعـلماري مكانـة مهمهـة لــدى المعلعاريـين،

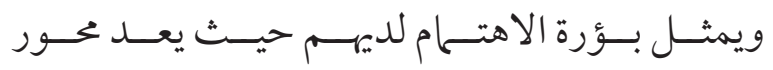

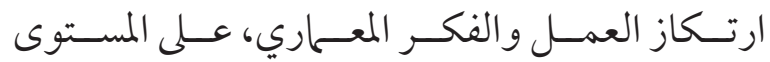

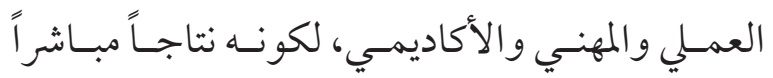

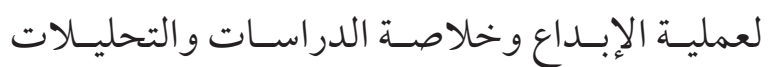
والأبحــاث المتعمقــة في كافـة التخصصــات المرتبطـة

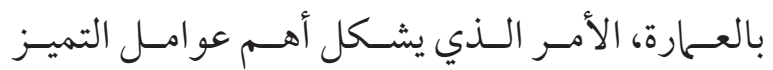

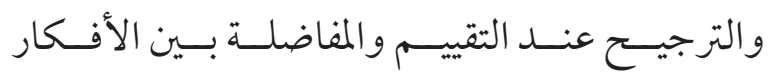

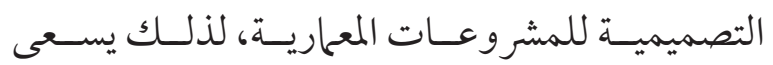

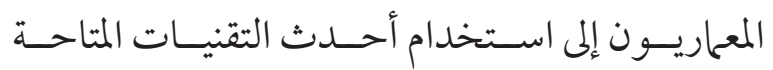

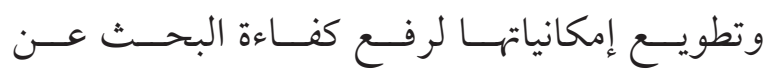

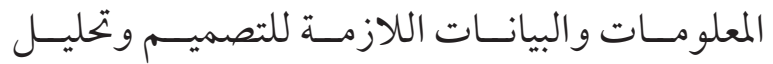
ونمذجــة معلومهـات الحــل المقــترح للمشـــاكل و القضايــا المعلماريــة في صــورة مرئيسـة تمكنهـــم مــن

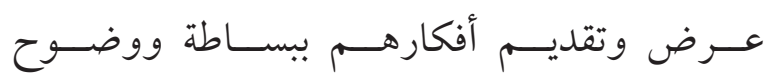
(Krietemeyer, et al. 2019)

نظـــراً للتطـــور الكبــير الحـــادث في تقنيــات

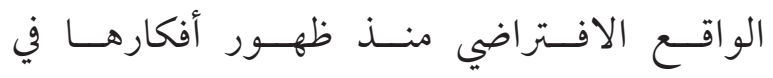

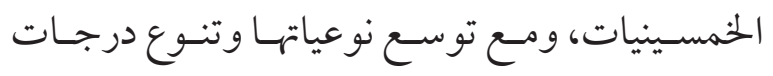
الارتبــاط بــين البيئــات الافتراضيــة والبيئــات

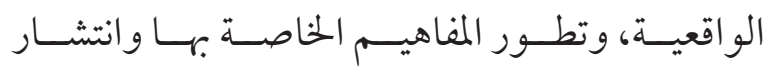


باســتخدام البرامـــ ثنائيــة وثلاثيــة الأبعـاد دون تفاعـل فعـلي مــع البيئـة التـي يتــم التصميــم فيهـا.

ه الأهـــداف: يتمثــل الهـــف الرئيسـسي لهــذا

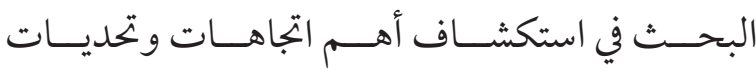

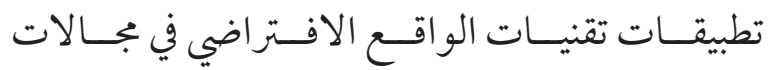

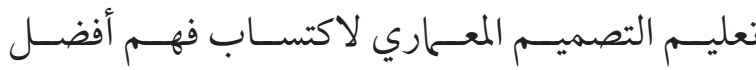

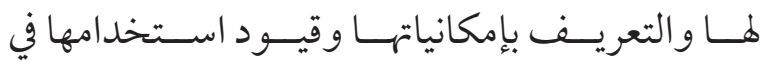
هـذا المجــال؛ لدعــم المختصــين التربويـين في مجـال تعليـم التصميـم المعــاري في بحــث وســائل تعظيـم الاسـتفادة منهــا في بيئـات تعليـم التصميـم المعـماري مـن جهـة، ودعــم الباحثـين في جــالات تطويـر هـذهـ

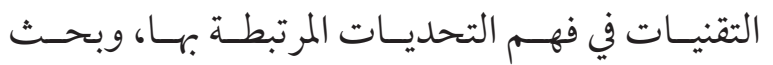
إمكانيـات توفـير الحلــول الملائمــة للبيئـات التعليميـة

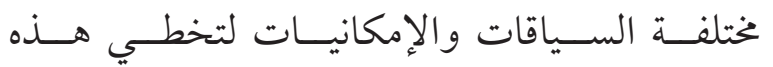
التحديـات مـن جهــة أخـــى .

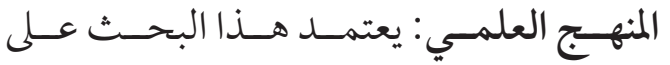

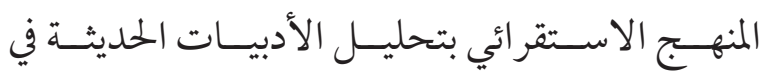

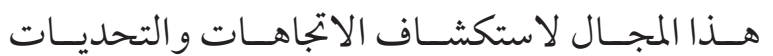
ذات العلاقـة بتطبيـق تقنيـات الواقــع الافـتراضي في تعليـم التصميـم المعــاري ودعــم التحليـل بعـرض

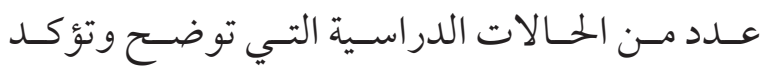
مـا يتــم التو صـل إليـه.

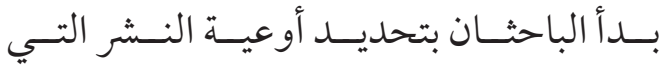

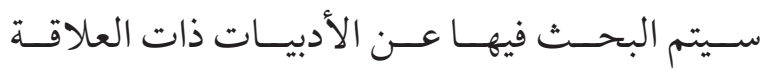

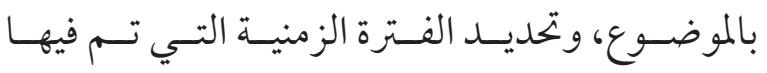

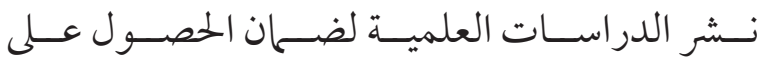

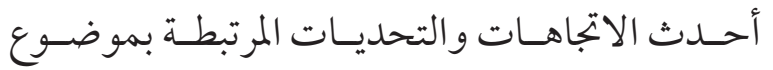

بالخصائصص الحسـية والإدر اكيـة للمسـتخدم، و الثـاني بقــدرة المسـتخدم عـلى اكتسـاب الخــبرات الشـخصية

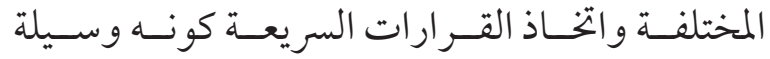

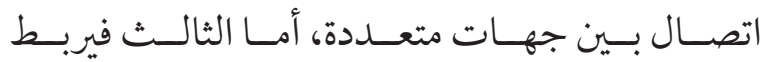

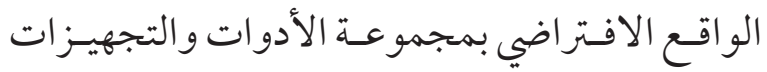
التقنيــة الخاصــة بينـاء عرو ضـــهـ و مشــاهداته. ويمثــل الواقــع الافــتراضي والبيئــات

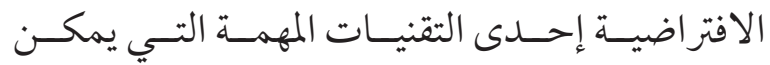
توظيفهــا في جــال تعليـم التصميــم المعــاري و التـي يمكـن مـن خلالهـا عمــل تصـور لشـكل البنـاء و أخذ تصـور عــن العلاقـات المكانيـة والإنشـائية وإيجـاد أماكـن الخنلـل والحلــول (Noghabaei, et al. 2020)،

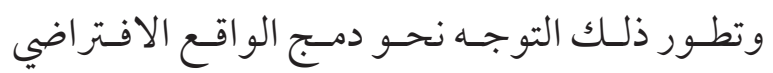

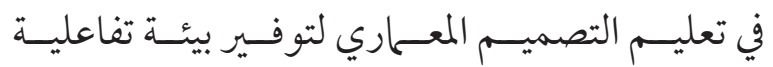

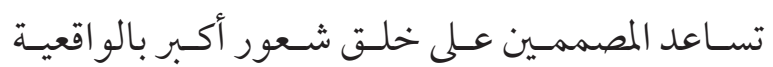
وقـــرة أكــبر عـلى التخيـلـل والإبــداع والابتـــار

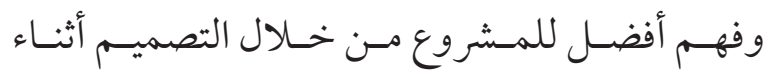

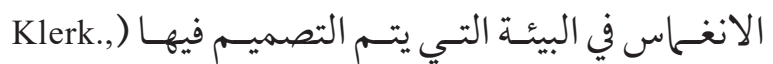
.(et al. 2019 هالإشــكالية البحثيــة: بالرغــم مـــن انتشــار

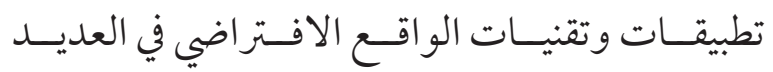

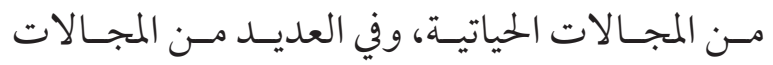

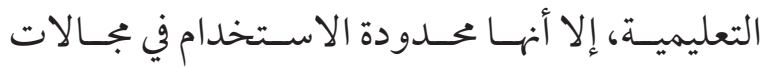
تعليـم التصميـم المعـلماري: فأغلـب كليـات العـلـارة

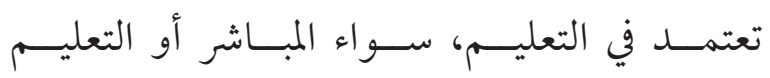

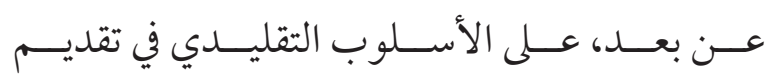

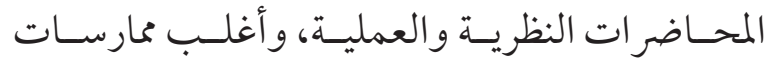

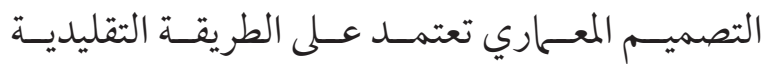


الخصــوص، والإمكانيــات المتعــددة التـي تمكــن

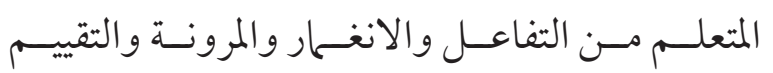

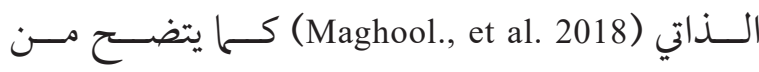

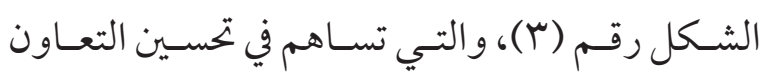

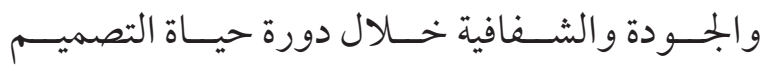

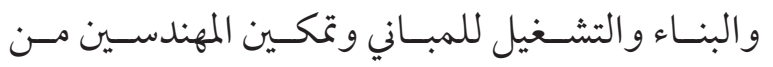

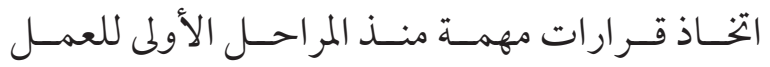
التصميمسي (Tepe., et al. 2018).

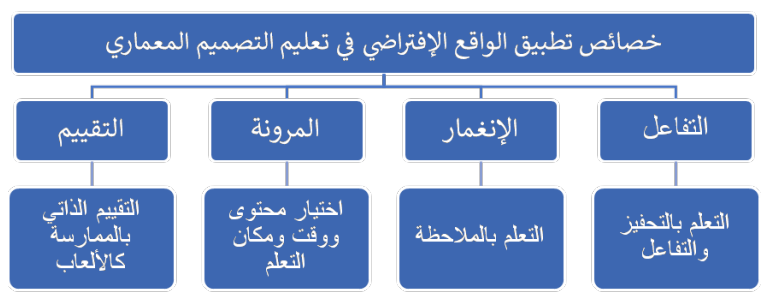

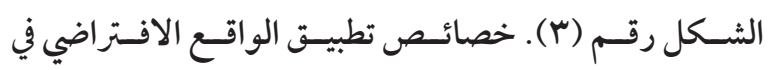

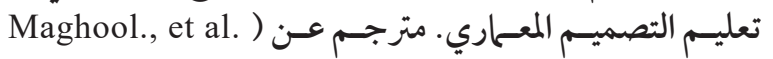
.2018

اتضـح مـن المراجعـات الأدبيـة تنـوع وانتشـار

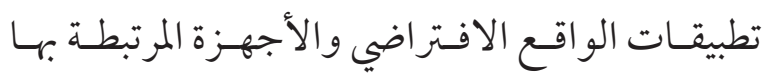

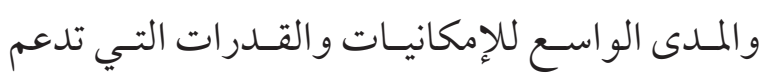

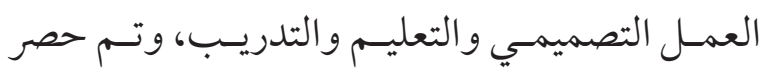

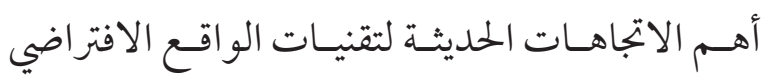

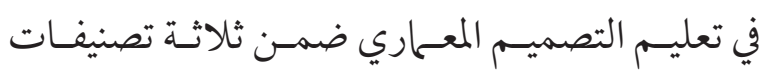

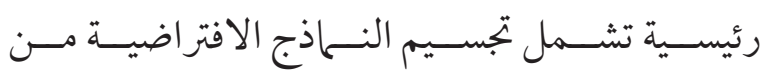

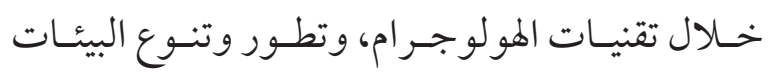

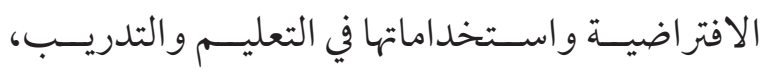

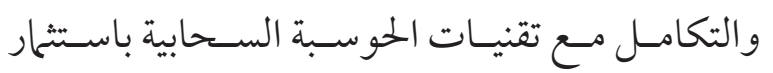

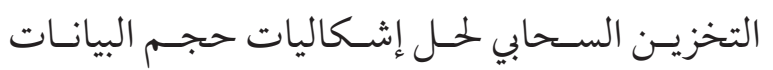

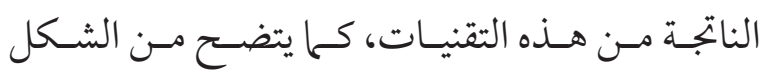

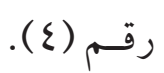

البحـث، ثـم فلـترة النتائسج عـلى مسـتويات ثختلفــة

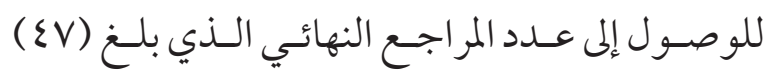

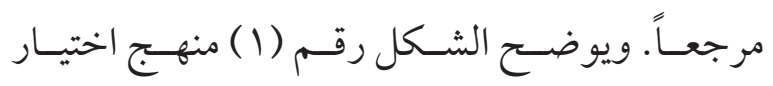

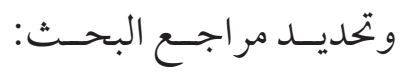

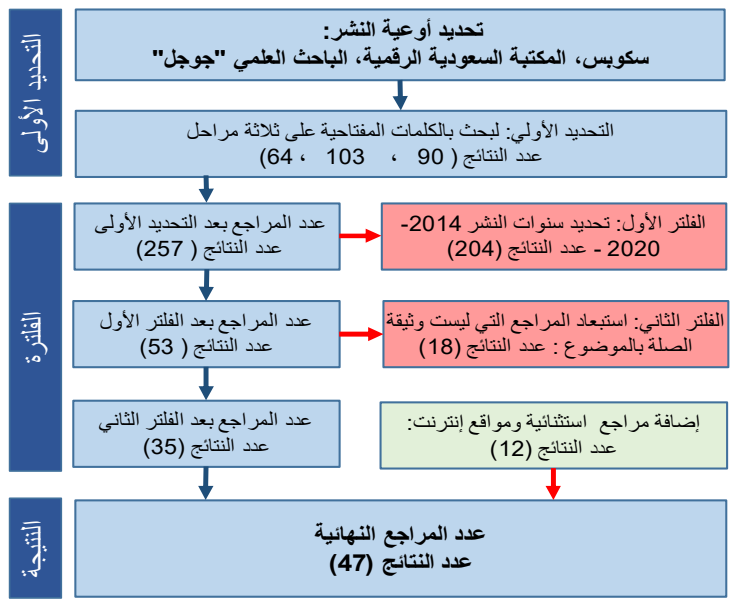

الشكل رقم (Y) . إجراءات تحديد مراجع البحث

r. الاتجاهات الحديثة لتقنيات الواقع الافتراضي في تعليم التصميم المعماري

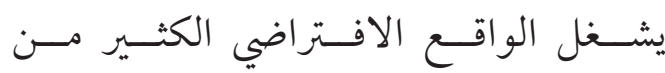

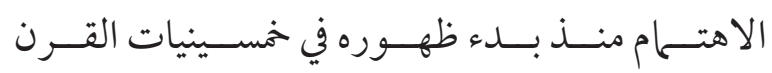

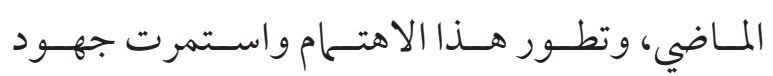

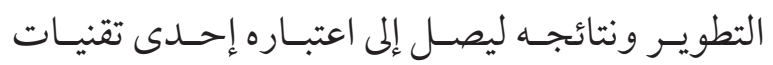

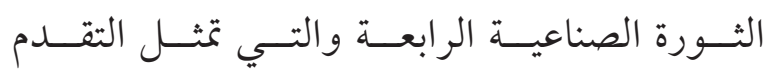

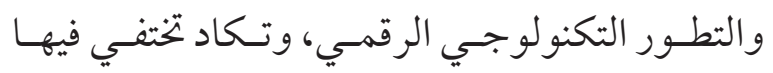

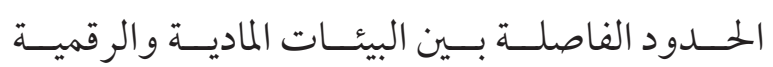

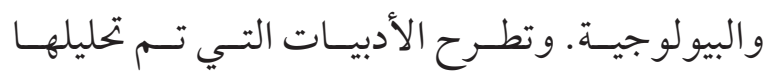

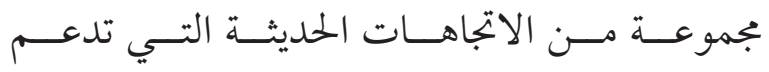

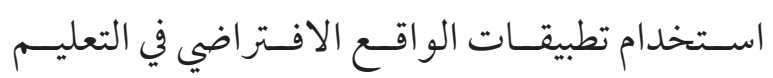

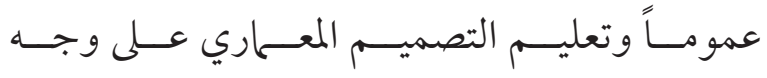


صناعـة الهولوجـــرام النابـض لتسـجيل الشـكل المـراد

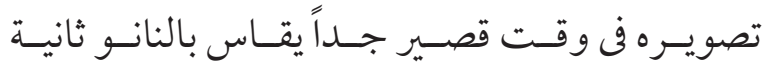

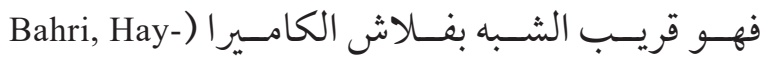
. (them ., et al

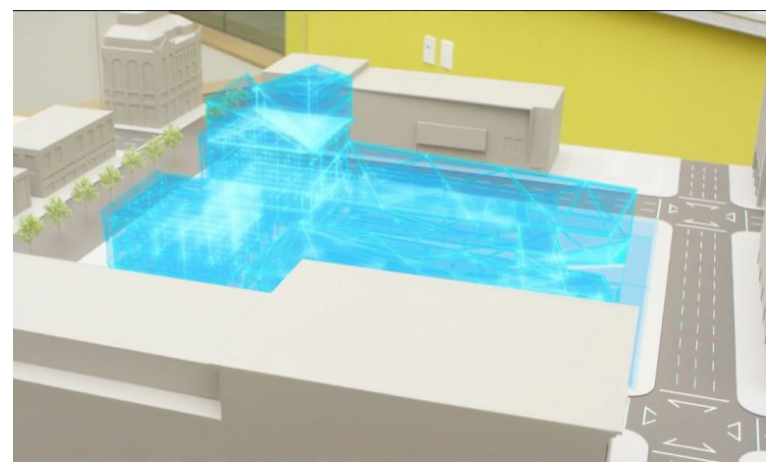

$$
\begin{aligned}
& \text { الثـكل رقـــم (ه). مسـتعرض اسـكتش أب مــن خــلال }
\end{aligned}
$$

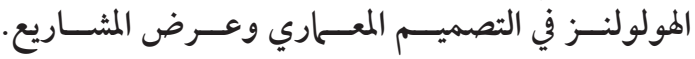

https://news.microsoft.com/transform/design-revolution-microsoft-hololens-mixed-reality-changing-architects-world/

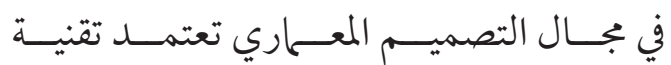

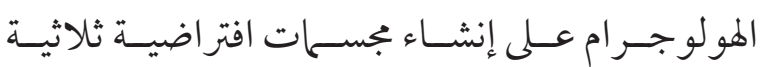
الأبعـاد مبـاشرة مـن النـاذج الرقميـة ثلاثيـة الأبعـاد

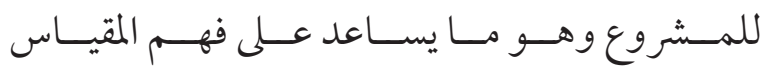

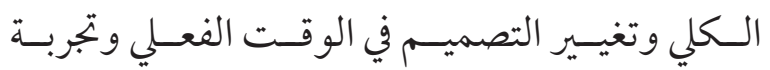

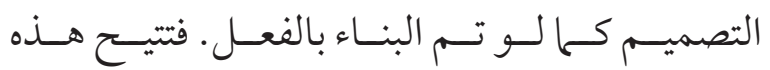

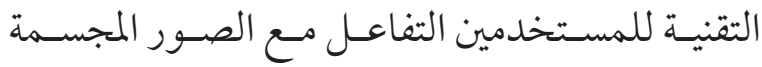

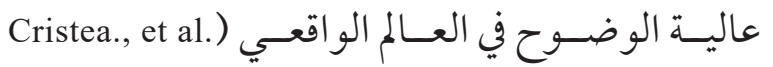

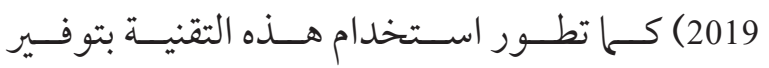

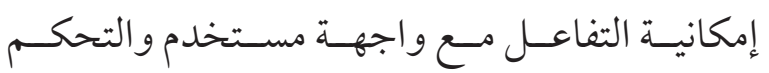

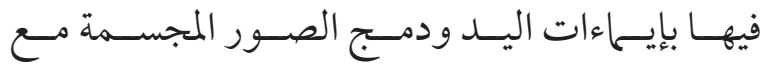

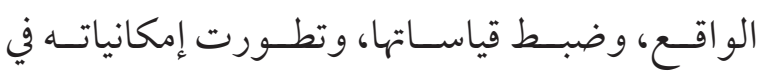
تحقيـق التـــوع في التشـــيلات اللونيـة باســتخدام
أبرز الإتجاهات الحديثة لتقنيات الواقع الإفتراضي في تعليم التصميم المعماري لت التيات
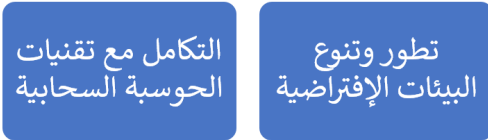

تجسيم النماذج تالجنتراضية

الشـكل رقـم (ع ). تصنيفـ أهــم اتجاهـات الواقع الافتـراضي المستتتجة مـن المراجعـات الأدبيـة.

وسـيتم في الجــزءء التـالي اسـتعر اض وتحليـل

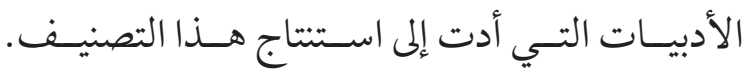

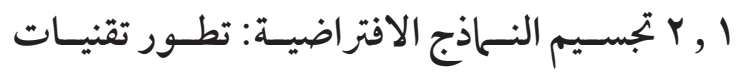

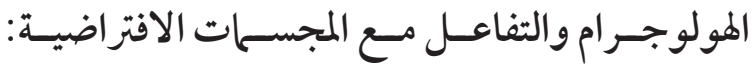
يمكــن اعتبــار الهولوجـــــام إحسـدى تقنيــات

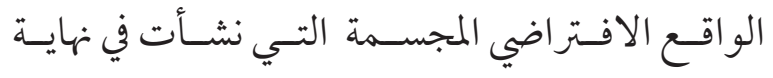

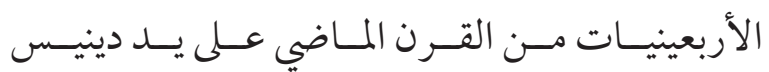
جاربــر (IHMA, 2020) ولكنـهـ تطـور بصـورة كبـيرة

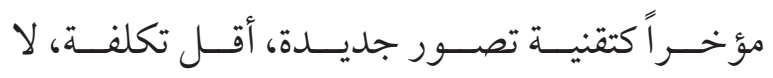

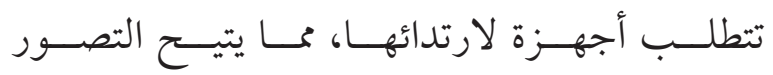

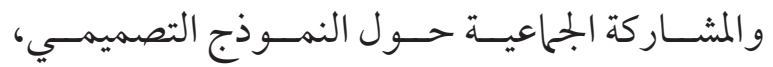

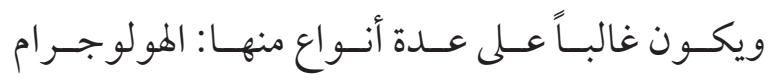

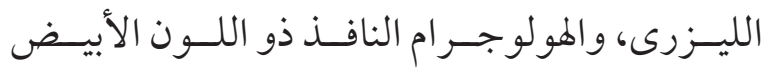

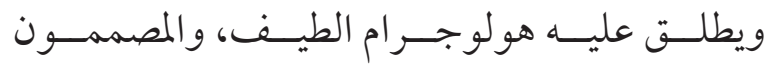

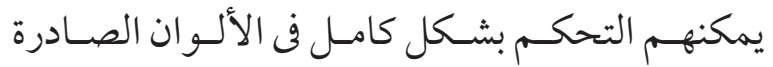

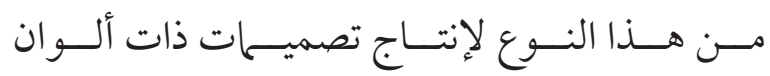

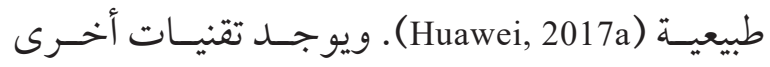

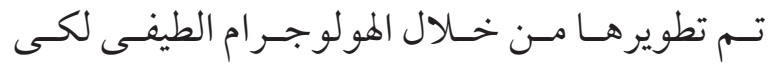

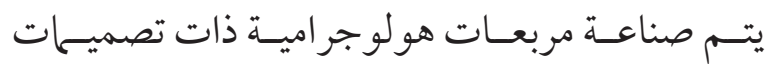
متحركـة لإظهـار الحركـة وزيـادة إمكانيـات الإنتـاج

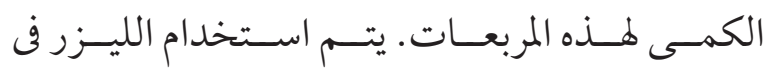




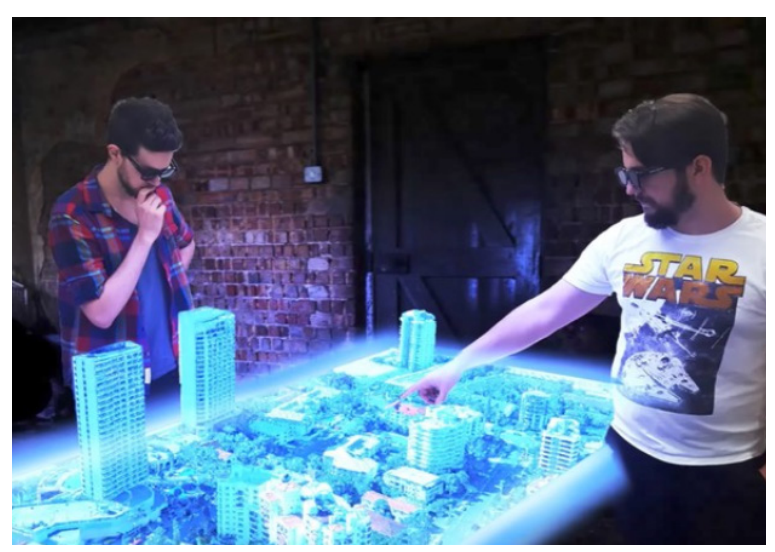

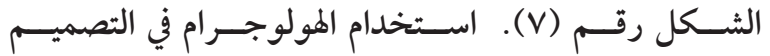

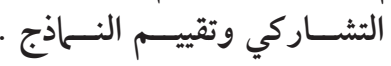

https://www.archdaily.com/878348/the-worldsfirst-hologram-table-is-here-and-could-be-yoursfor-47000-dollars

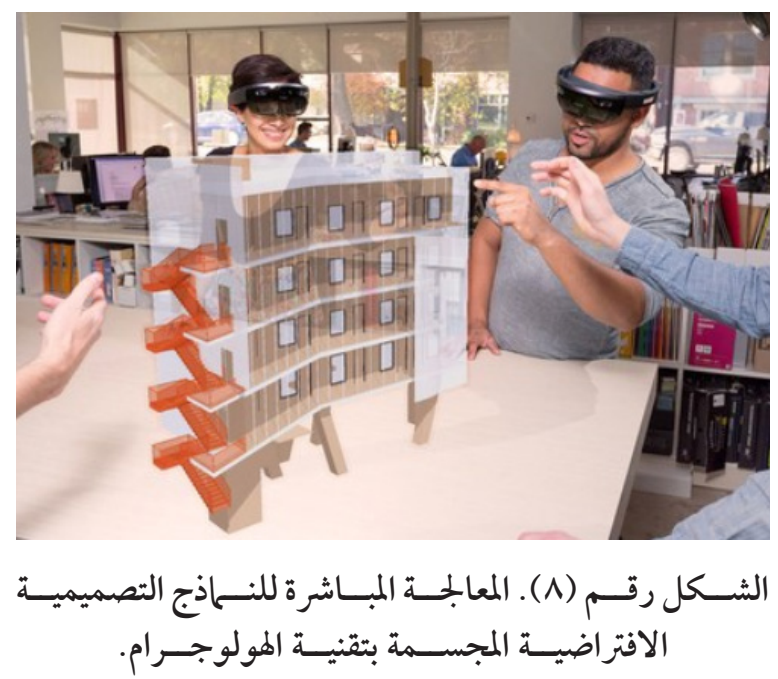

https://www.archdaily.com/878348/the-worldsfirst-hologram-table-is-here-and-could-be-yoursfor-47000-dollars

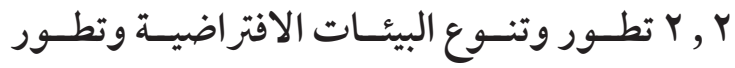

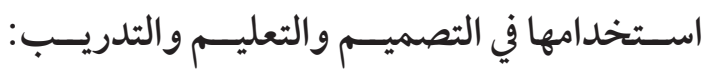

يمكـن مـن خـالال البيئـات الافتر اضيـة ثلاثية

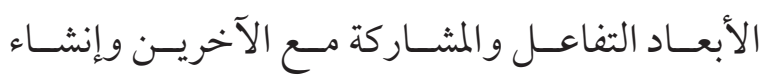
كائنـات كجــزء مــن هــذا التفاعـل، حيــث يظهـر المسـتخدمون كصـورة رمزيسة في العـالم الافـتراضي:

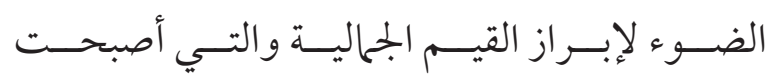

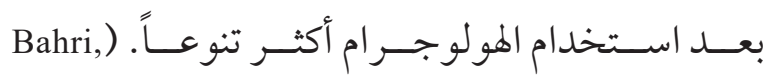
(Haythem ., et al ولذلـك تــم تطويسـر اسـتخداماته في بــال التصميــم المعـــاري بشـكل واسـع النطـاق وخاصــة في جــالات التصميــم التشـاركي ومعاينـة وتقييــم النــاذج التصميميـة المعقــدة في بيئـة افتراضيـة

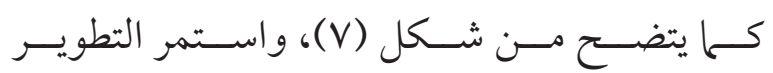
ليشــمل إمكانيـة معالجــة وتعديـل النــاذج مبــاشرة

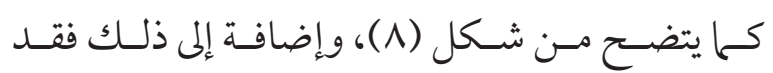

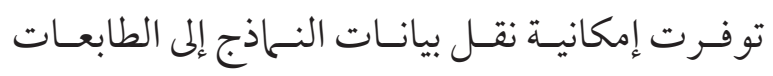

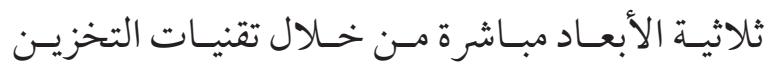

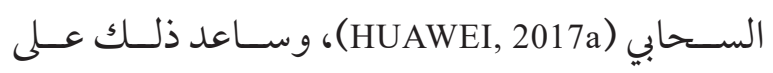
تحقيـت تعــاون وتفاعـل أكثـر مــع النـاذج التصميميـة

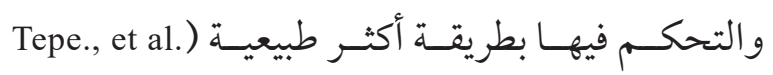
2018) و. ولـكل مـا سـبق يمكــن اعتبــار هـذه التقنيـة مـن أهــم و أبـرز التقنيـات التـي يتوقـع أن يكـون لهـا

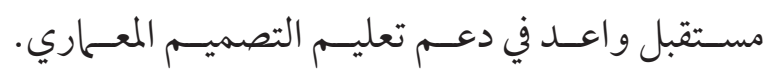

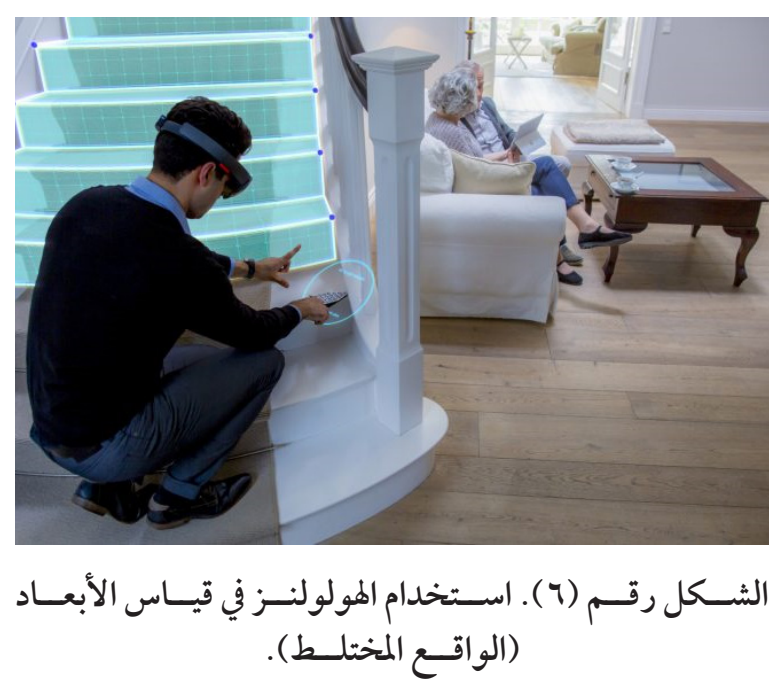

https://nl.letsgodigital.org/virtual-reality-vr/microsoft-hololens/ 
تهـــف العــوالم الافتراضيـة في بمملهــــا إلى

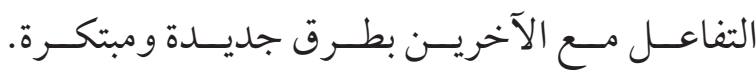

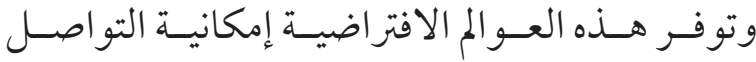

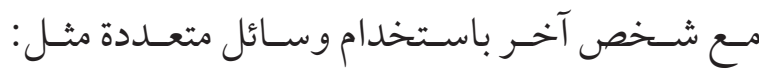

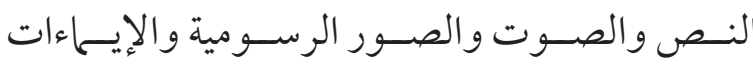

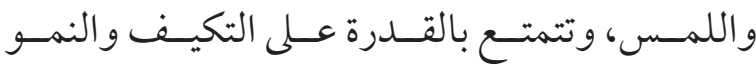

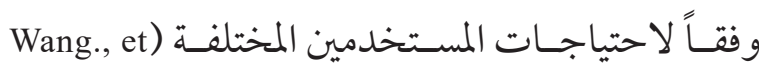

(.al. 2018

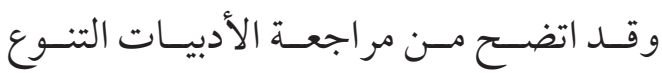

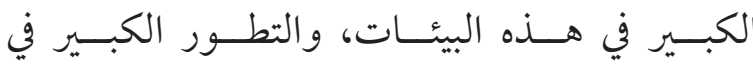

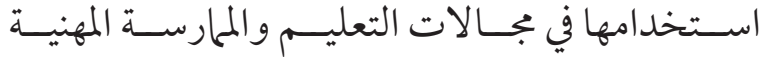

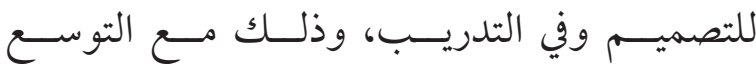
والانتشــار في اسـتخدام شـبكات الإنترنــت

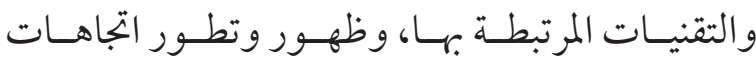

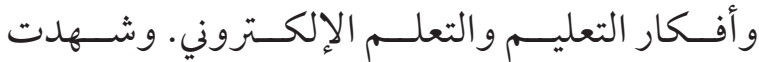

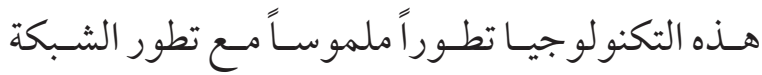
نفسـها، وظهـرت تقنيـات جديـــة داعمة لـــا التوجه

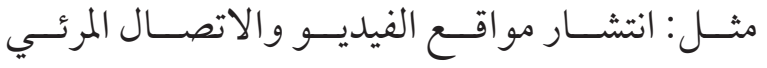
وبــروز اسـتخدام البيئـات الافتراضيـة وتطبيقاتهـا،

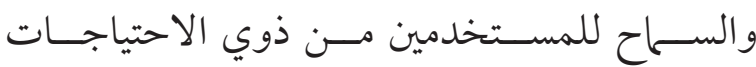

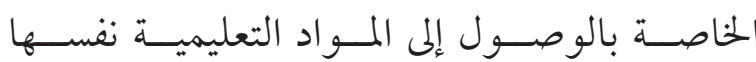

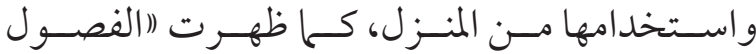

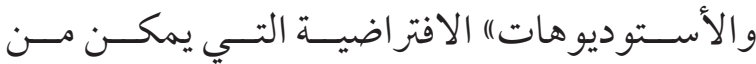

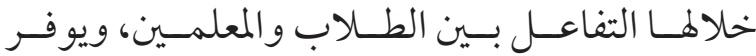

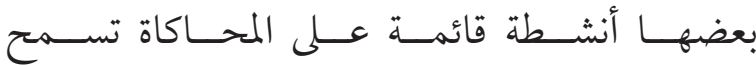

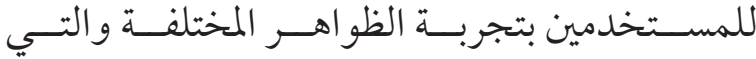

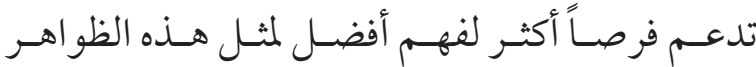

الصـورة الرمزيـة عبــارة عن تمثيـل افـتراضي يمكن أن

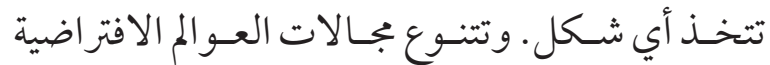

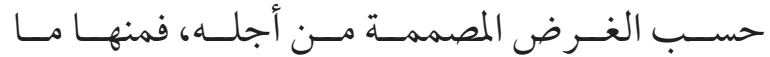

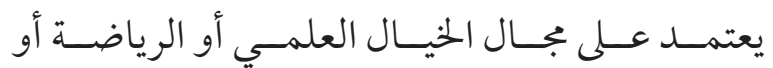

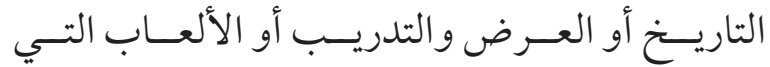

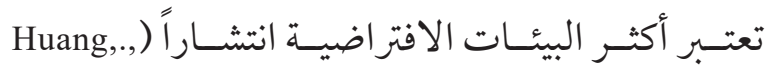

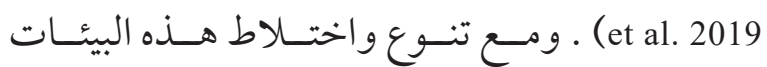

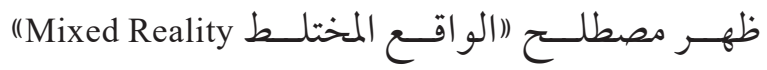

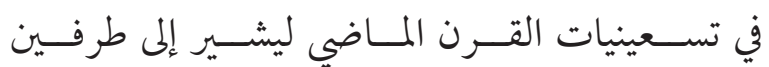

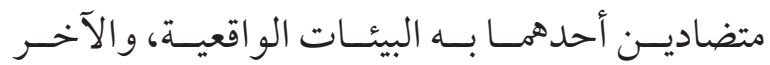

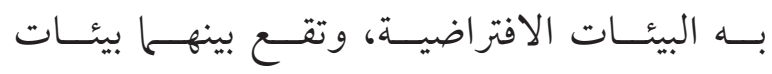

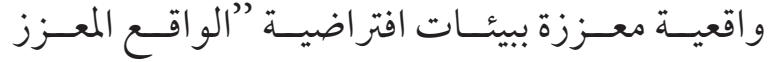

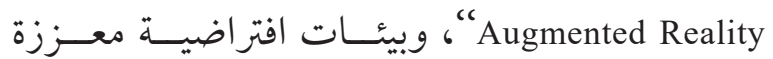
بيئـات واقعيـــة "البيئـات الافتراضيـة المعــــــززة Augmented Virtuality

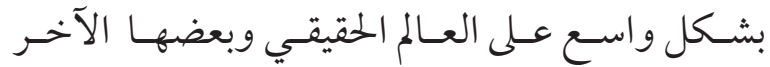

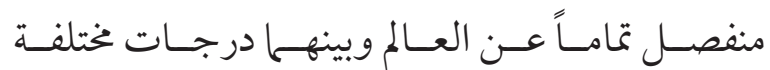

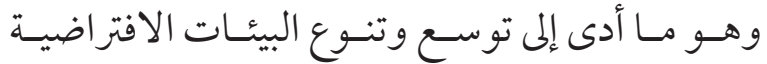

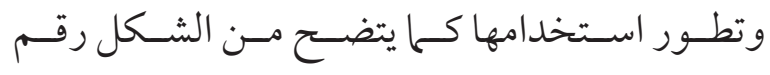

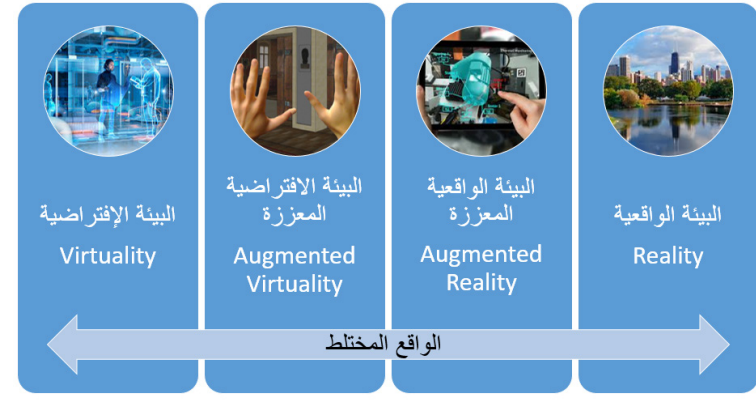

الشكل رقم (9). التنوع في مدى العوالم الافتراضية

( Milgram \& Colquhoun, 1999)

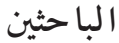




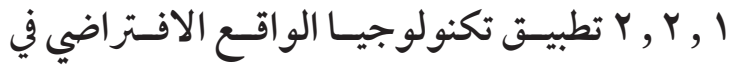
تعليـم التصميـم المعـاري

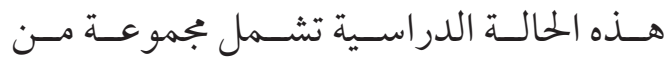

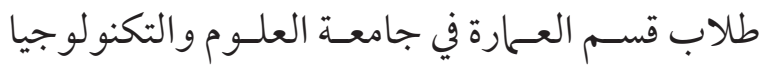

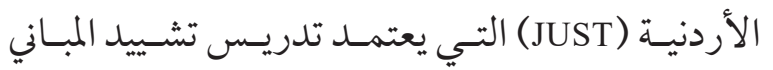

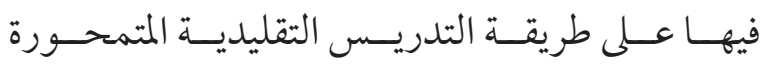

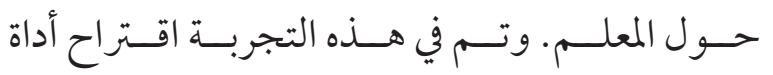

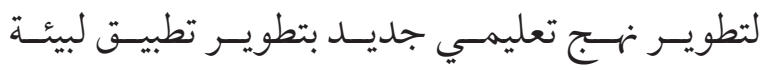

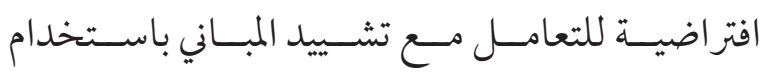

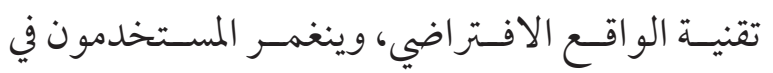

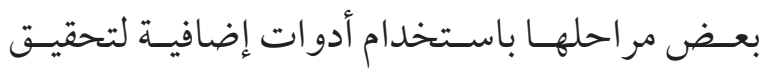

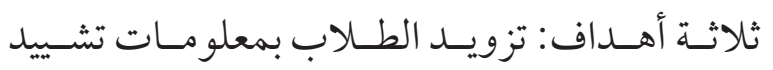

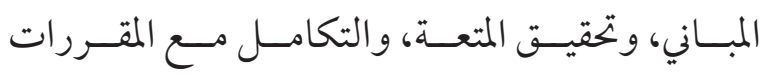

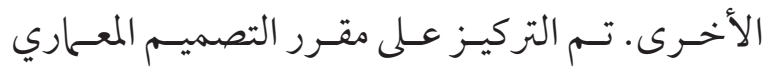

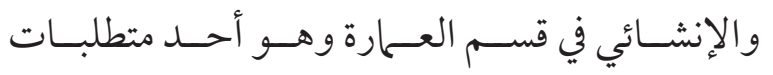

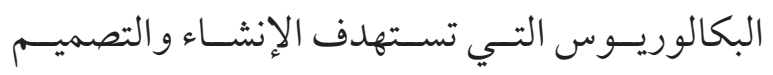

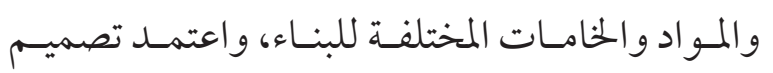
الحالــة الدراسـية عـلى عنـصري التفاعـل و المثــاركة

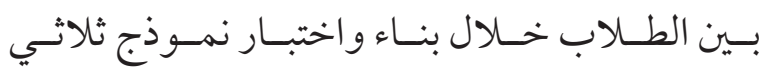
الأبعـاد لأحـــ المشـاريع التـي تتيـح لهـم فهـاً وإدراكاً

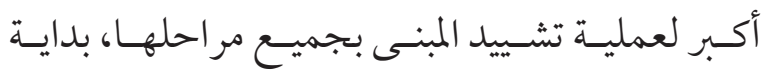

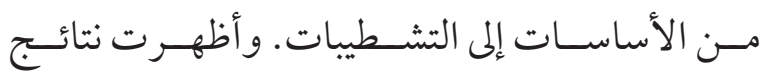

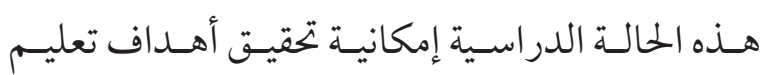

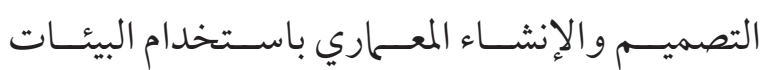

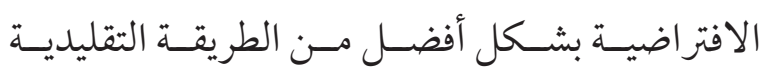

(Bashabsheh., et al. 2019)
التـي كان يصعـب فهمهـــــالطــرق التقليديـة (.Cruz-Benito., et al. 2016)

تعــود الأهميـة الخاصـة بتقنيــة البيئـات

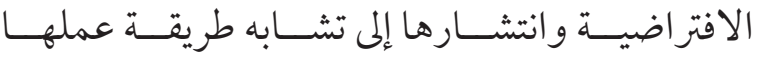

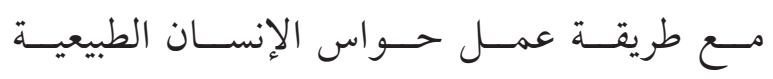

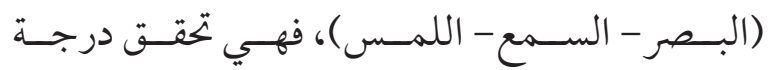

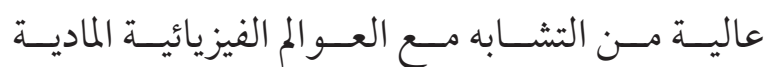

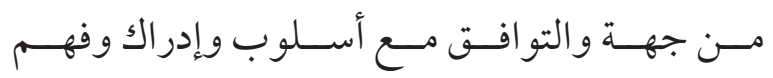

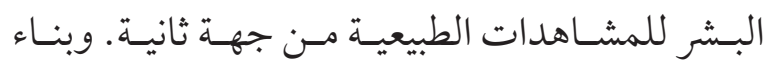

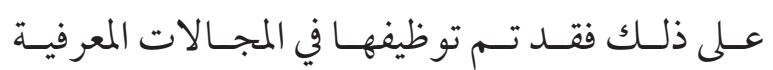

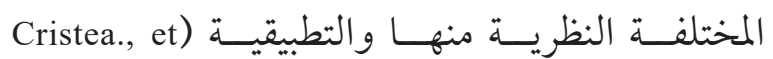

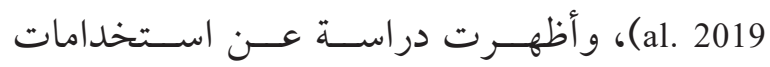

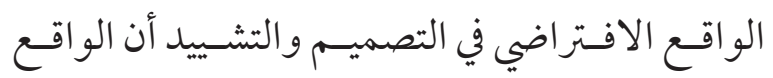

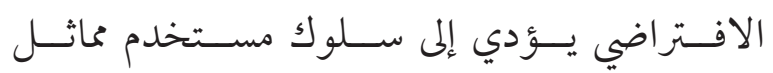

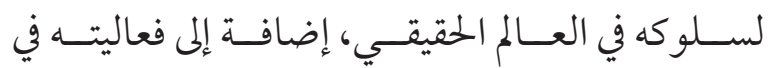

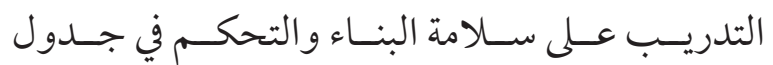

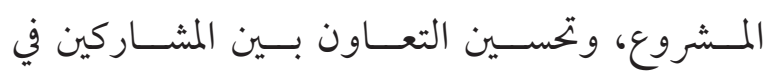

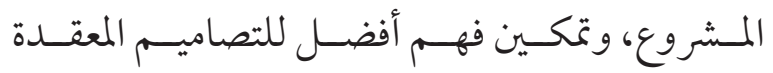

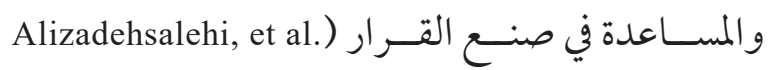
.(2019

ولكــون هـــه البيئـات أسـاس عمـل تقنيـات

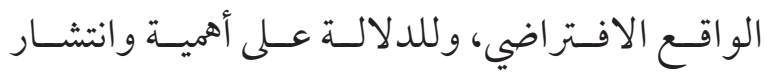

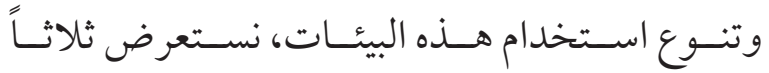

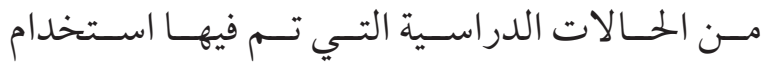

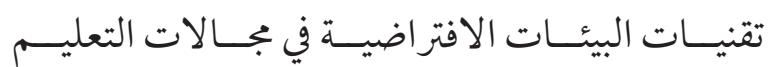

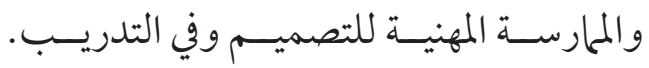




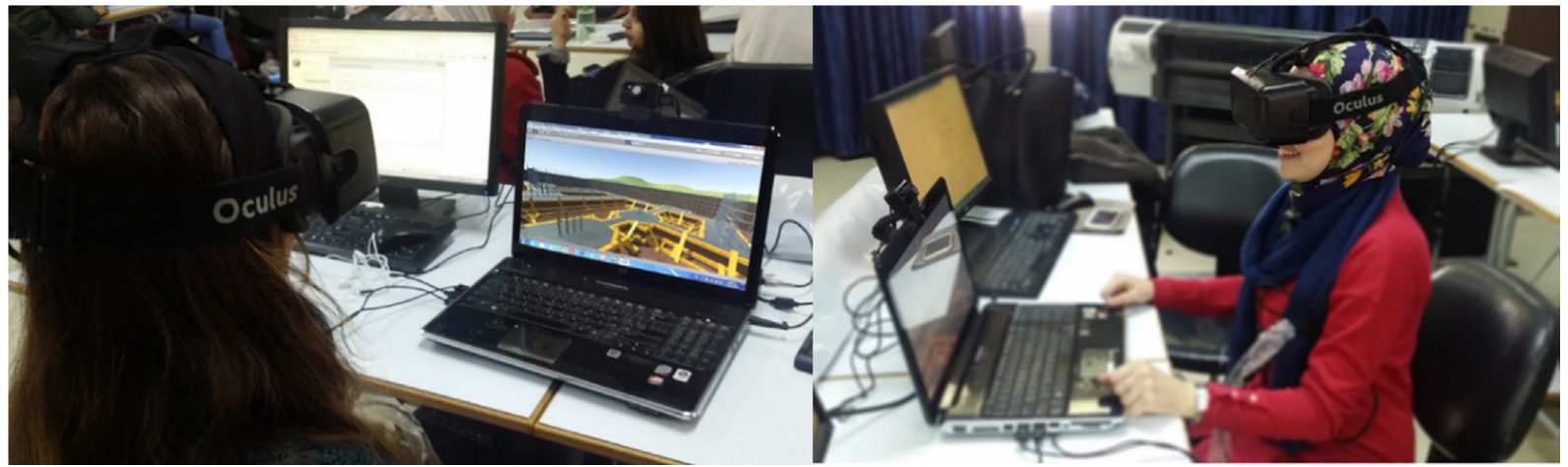

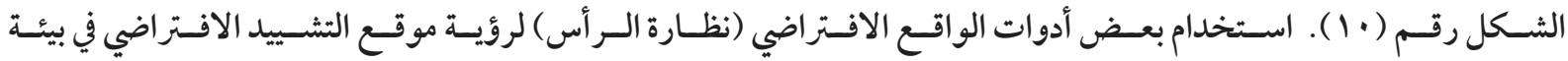
انغماريسة (Bashabsheh., et al. 2019)
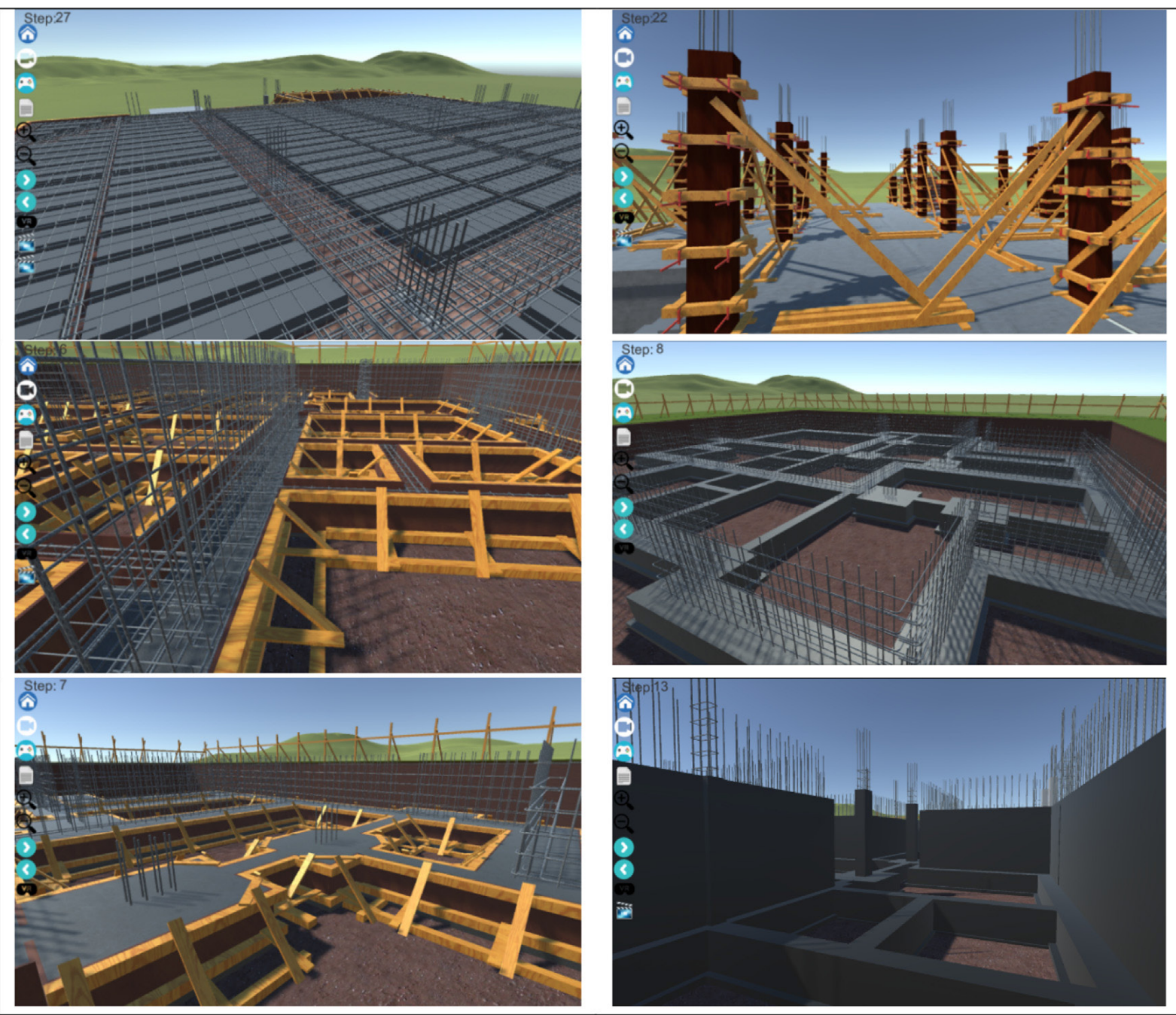

الشكل رقم (11). صور لبعض مراحل بناء البيئة الافتراضية (Bashabsheh., et al. 2019) 
عـرض التصاميسم لمختلـف المعنيـين بالمششروع مـن

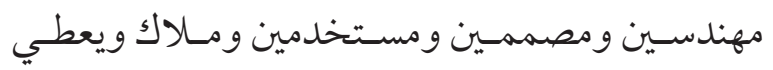

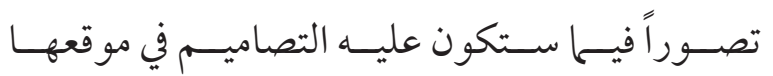

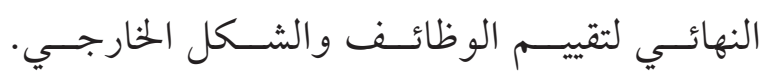

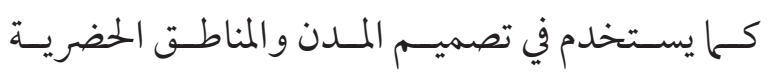

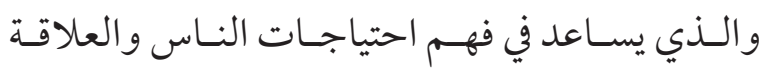

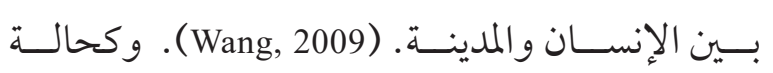

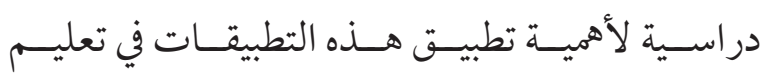

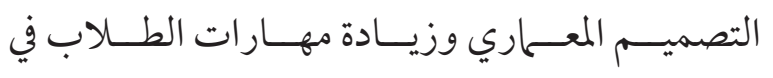

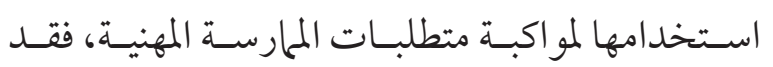

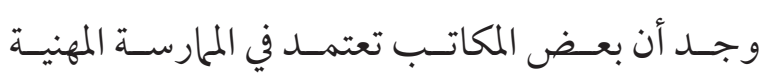

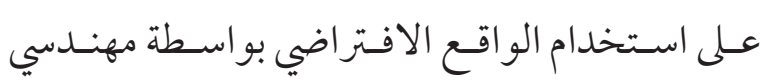

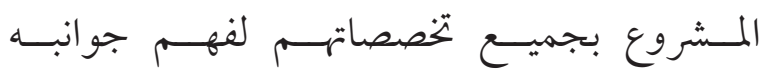

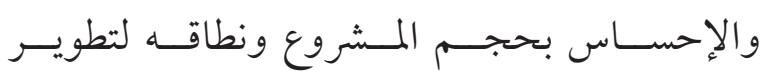

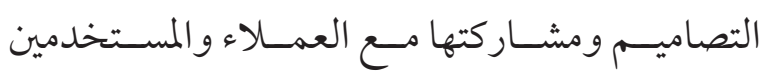

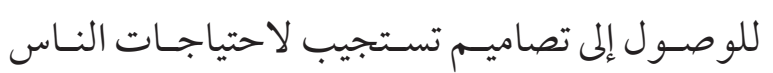
وتتوافـق مــع البيئــة (Noghabaei, et al. 2020).

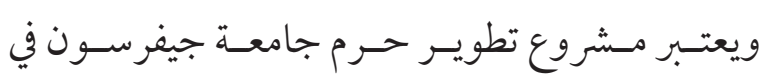

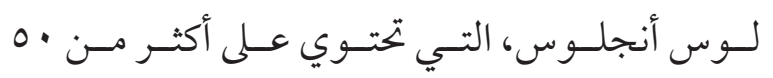

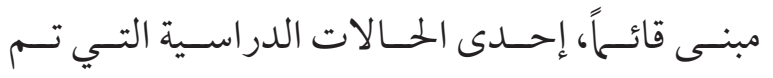

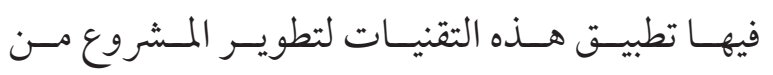

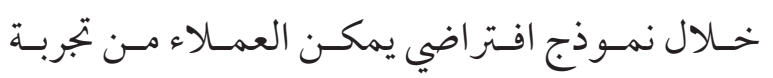

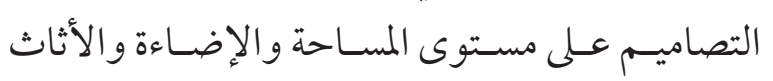

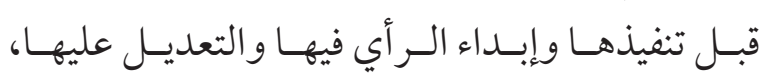

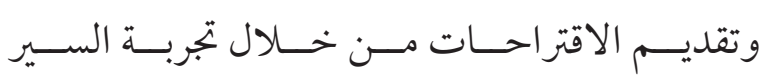

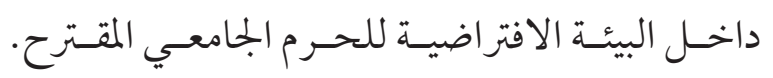
.(www.hmcarchitects.com) وقـــــ أثبتــت هــــه التجربــة أن اسـتخدام
وقــد أدى اسـتخدام البيئـات الافتراضيـة بهـــه

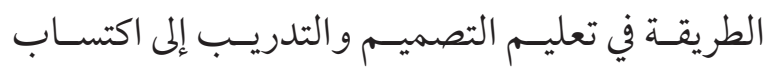

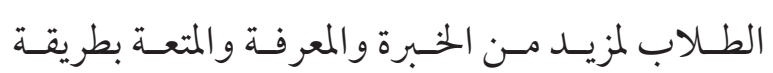

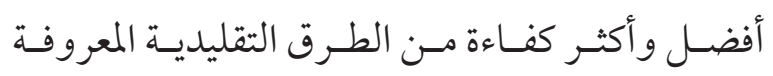

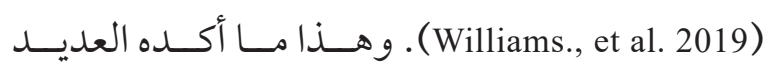

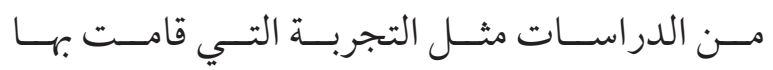
وخلصــت منهـــا إلى أن (Fonseca., et al. 2014) مسـتوى تفاعـل الطـلاب في جميـع مر احـل اسـتخدام

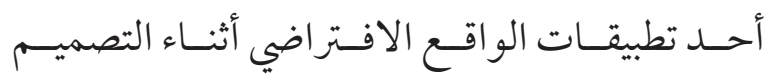

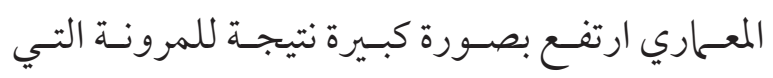

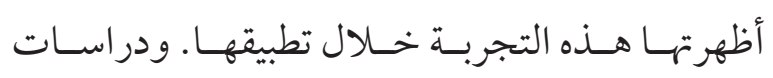
(Kharvari, Hohl. 2019)و (Maghool., et al. 2018)

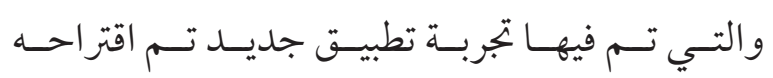

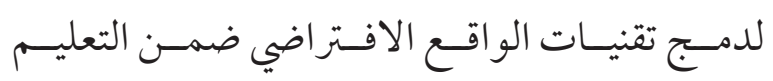

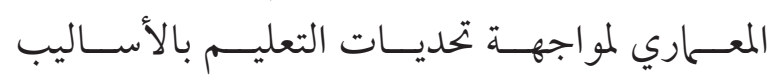

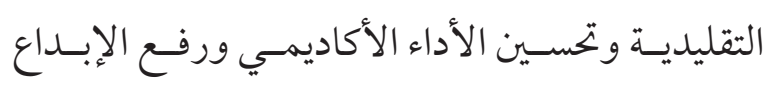

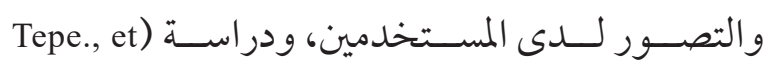

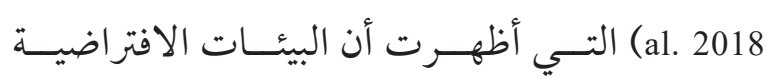

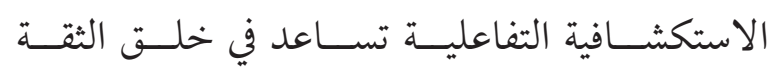
بالنفـس وتسـمح بالمشــاركة والتفاعـل بــين المستـتخدمين.

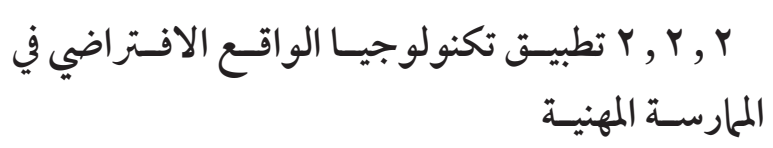
يستـخدم الواقـع المعـزز في مراحـل التصميـم

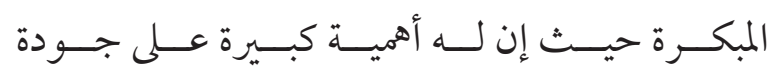

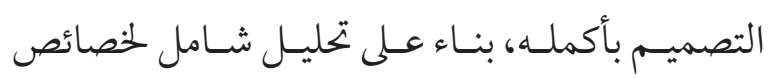

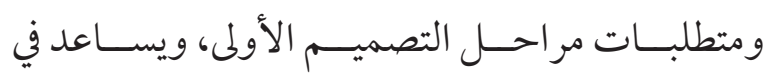


الوقــت والتكلفــة، خـلال بيئــة تعاونيـة وتشـاركية

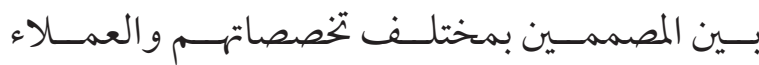
بمختلـف توجهاتهـم (Tian lo \& Schnabel. 2018).

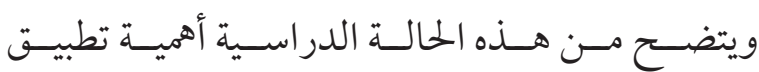
هـــهـ التقنيــات في البيئـات التعليميــة لتجهيـز

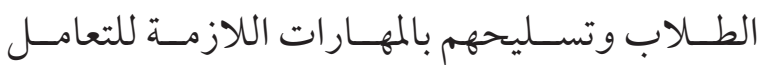
معهــا في الواقــع الفعـلي.

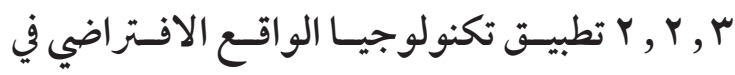

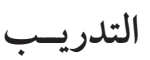

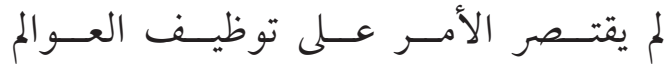

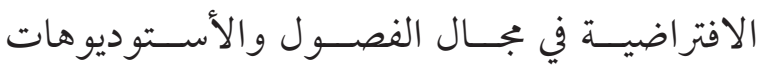

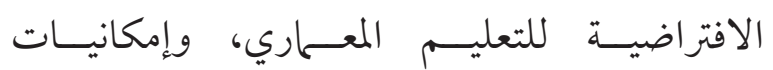

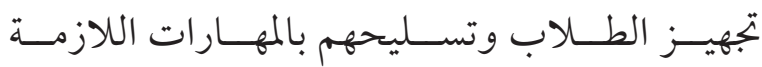

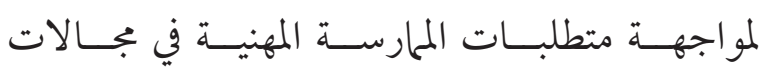
التصميــم التشـــاركي بــين المشــاركين في التصميــم

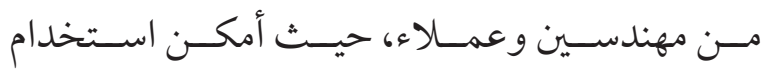

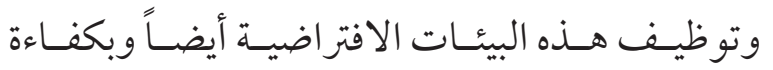

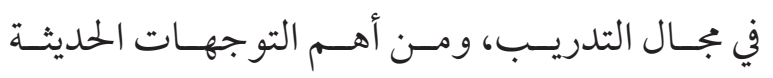

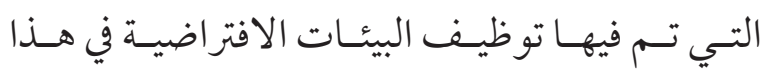

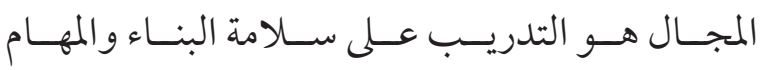

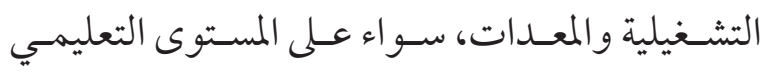

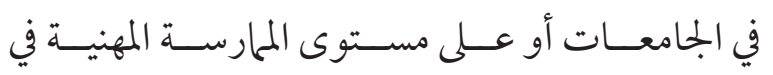

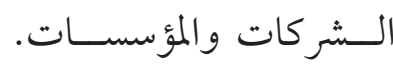

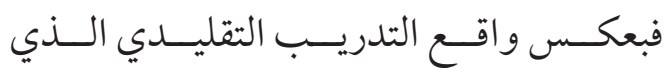

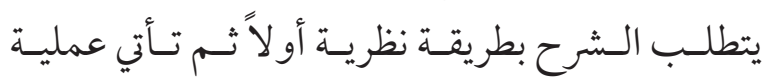

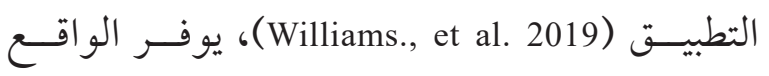

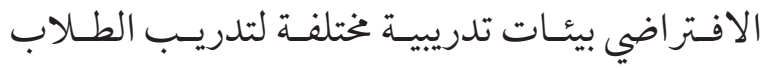

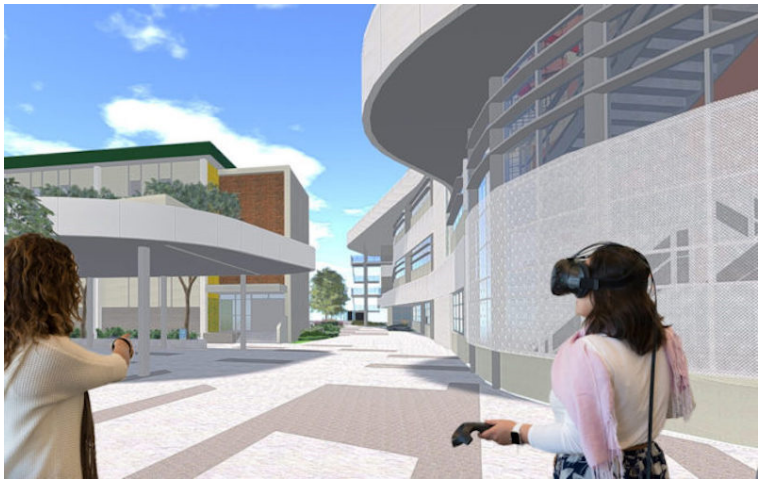

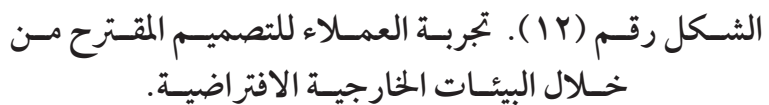
https://hmcarchitects.com/news/revolutionizing-school-design-with-virtual-reality/

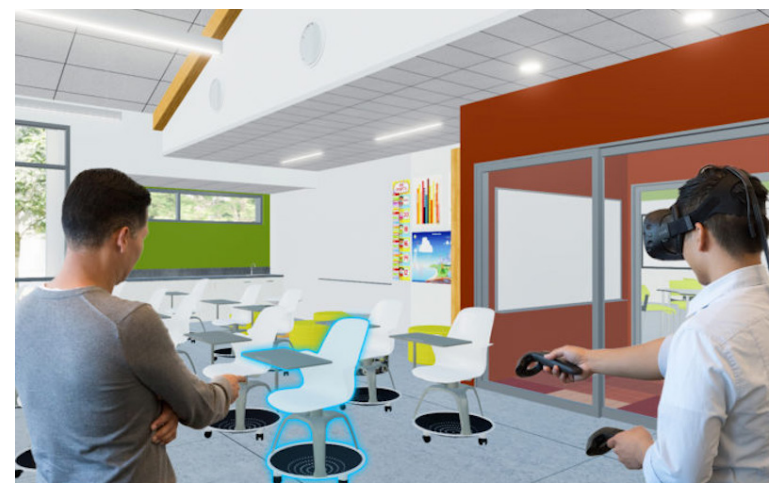

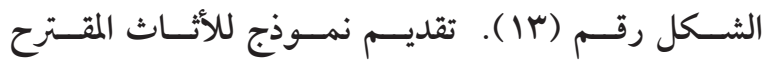

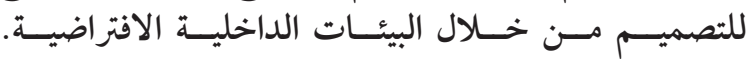
https://hmcarchitects.com/news/revolutionizing-school-design-with-virtual-reality/

الواقـع الافـتراضي في التصميــم يسـاعد المهندسـين

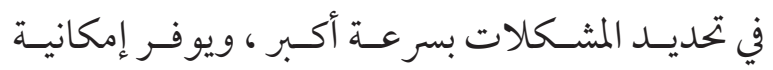

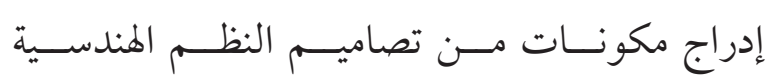

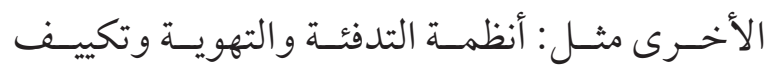

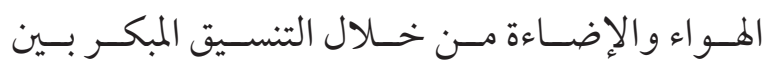

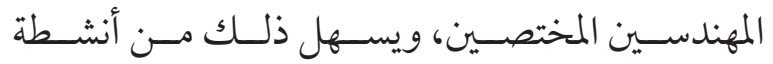

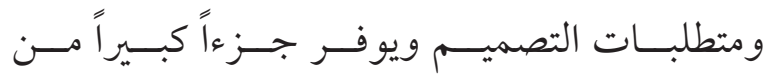



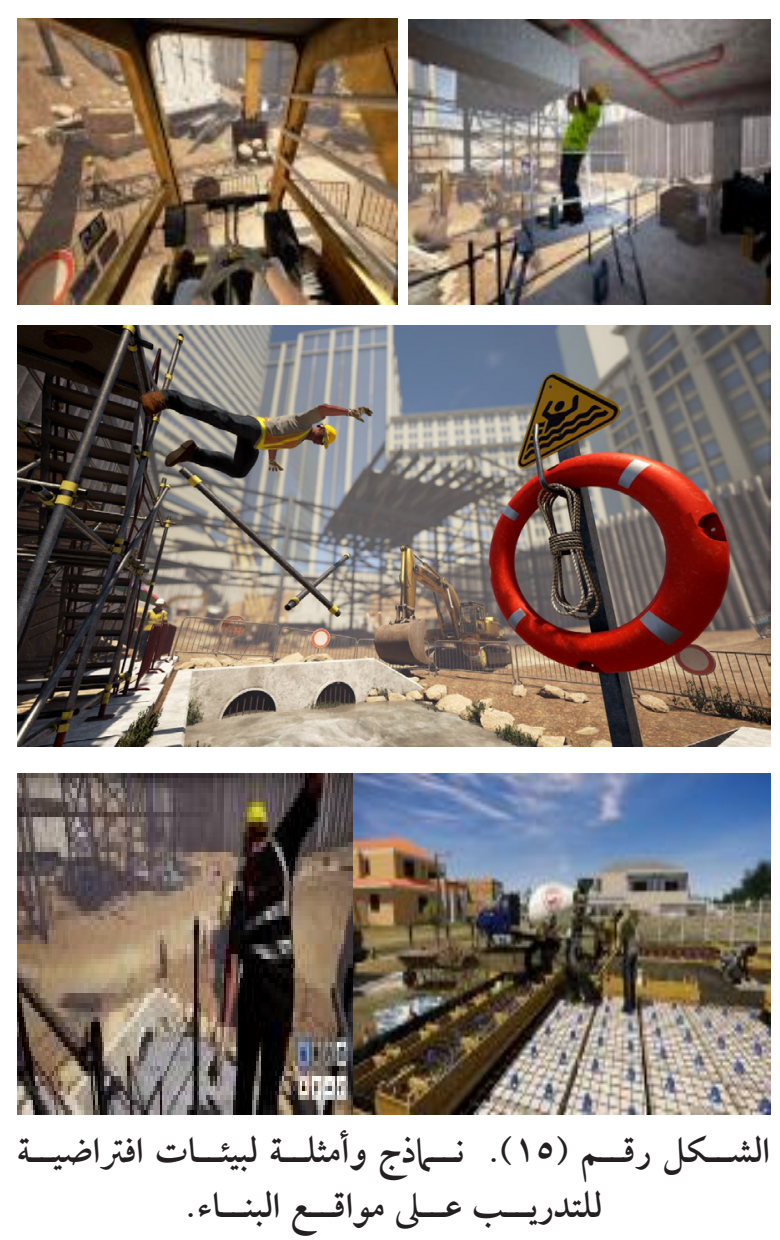

https://ccsbestpractice.org.uk/entries/the-situation-engine-experience-based-safety-training

مو اقـع البنـاء. وأوضحــت نتائسج بعـض الدراسـات

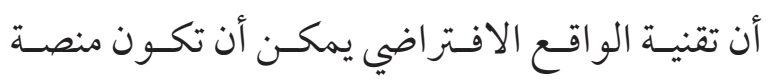

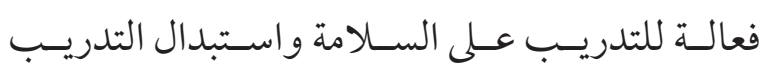

في الموقــع (Noghabaei, et al. 2020).

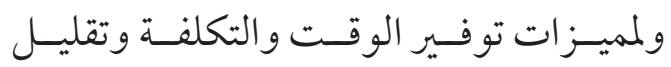

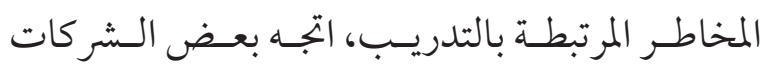

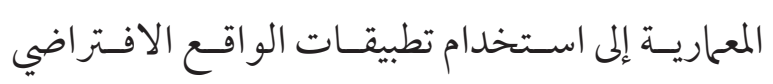

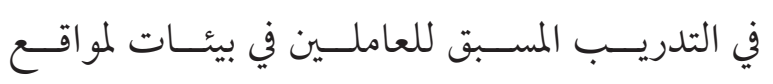

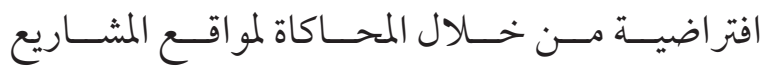

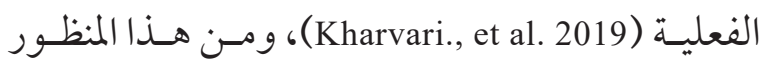

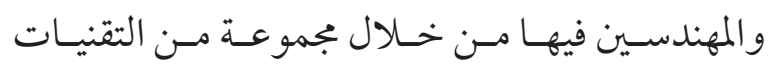

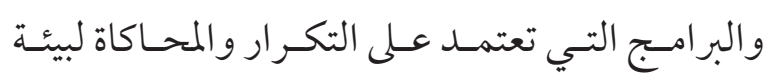

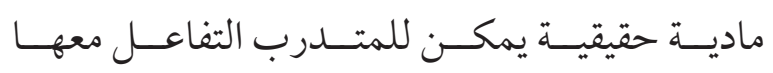

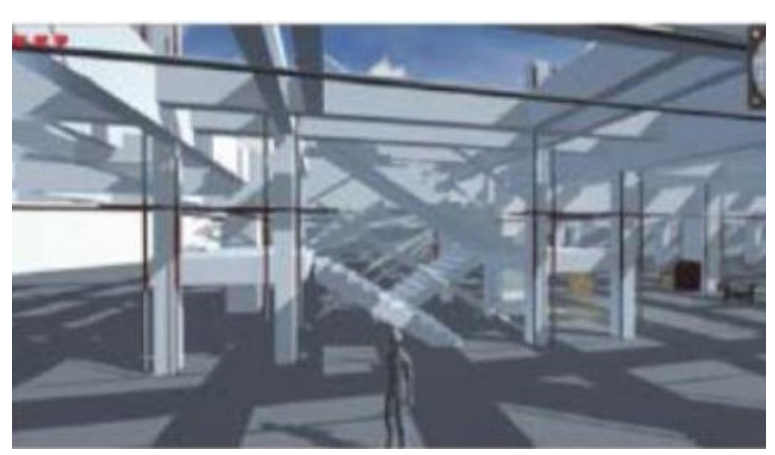

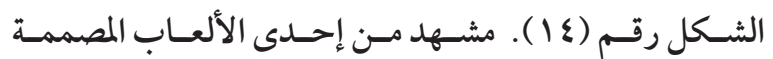

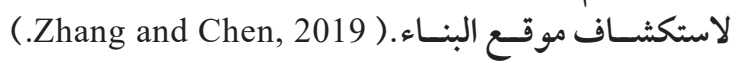

واكتســاب الكثـير مــن الخــبرات ومر اجعتهـــا في

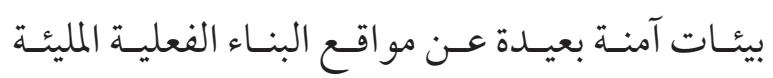

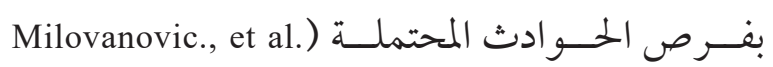
.(2017

يجقـق التدريـبـ في البيئـات الافتراضيـة العديد

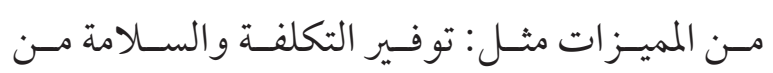

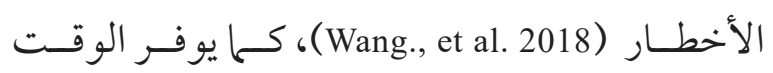

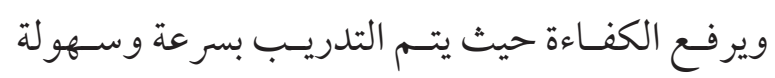

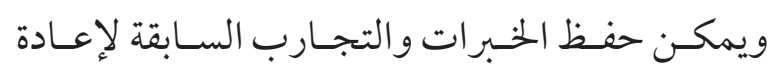

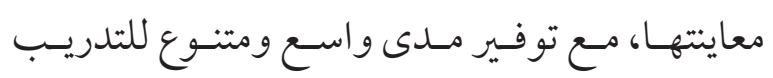

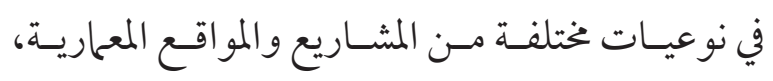

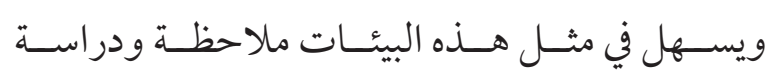

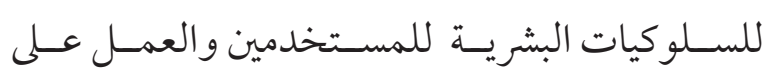

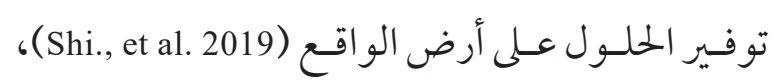

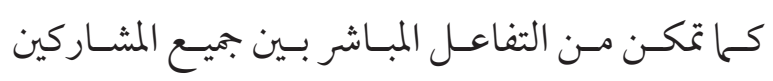

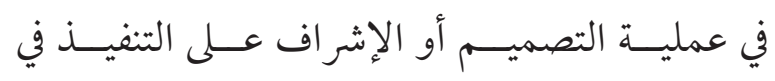


الو اقـع الافـتراضي في التعليـم و أدرجهــا تحــت فئتـين

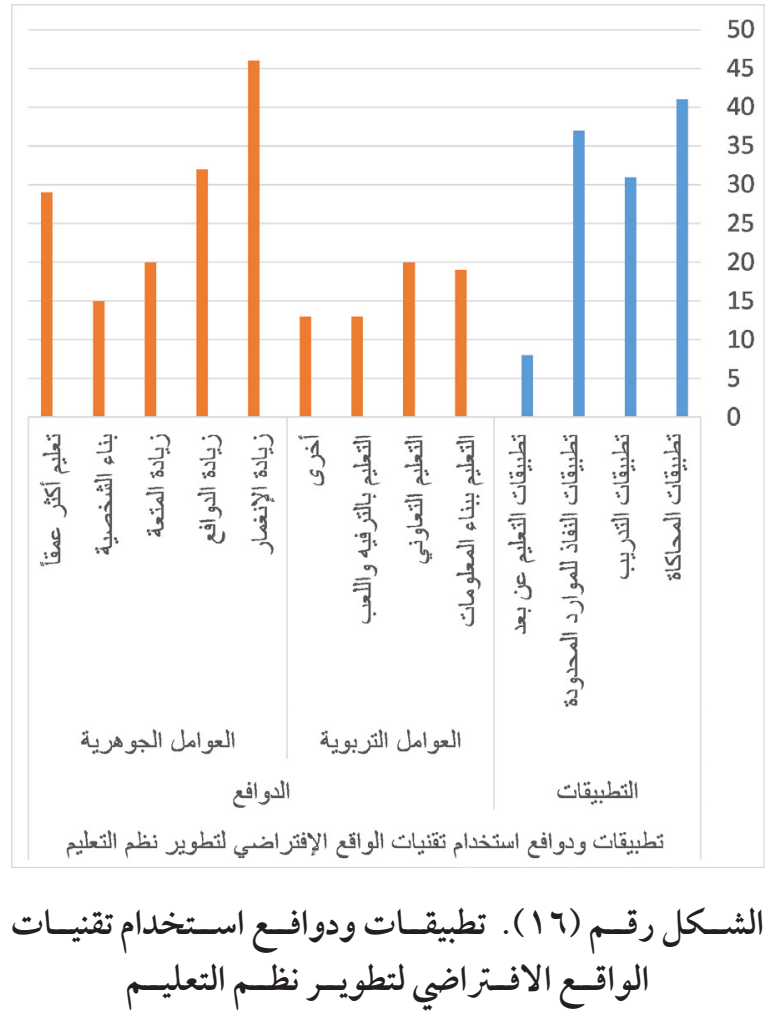

مترجم عن (Kavanagh., et al. 2017)

أساسـيتين: تطبيقـات ودو افـع، وصنـف الأخــيرة إلى

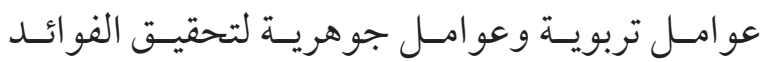

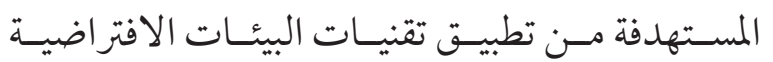

في التعليـم كـما يتضـح مــن الشـكل رقـم (7 ( ).

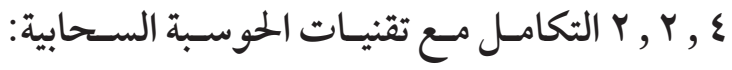 التخزيـن السـحابي}

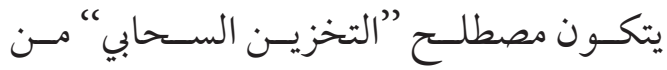

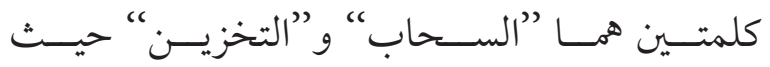

يتــم تشــيه الإنترنــت بســحابة هائلــة يمكنهـــا

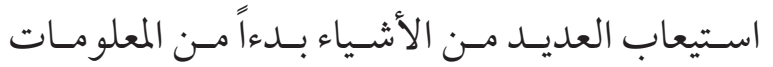

أيضـاً اتجـهـ بعـض الجهــات التعليميـة لدمــج الواقـع

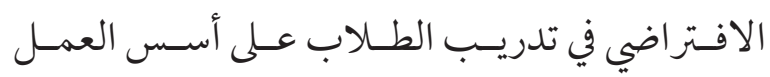
في مو اقــع البنـاء مــن خــلال بيئــة افتراضيــة يمكــن

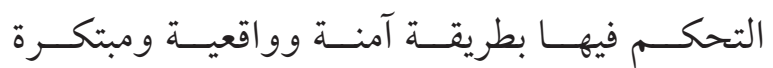
و مثمــرة، ويتو افــر بهــا الخدمـــات الفنيـة والتعليميـة التـي تمكــن الطـلاب مــن الحصــول عـلى الخــبرة

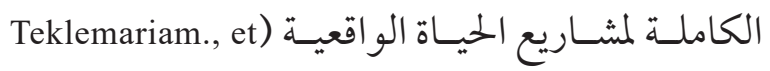

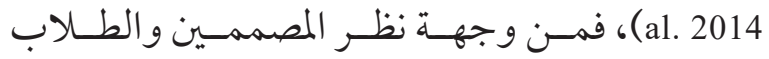
و المهندسـين يمكــن أن توفـر هـــه التقنيـات إمكانيـة

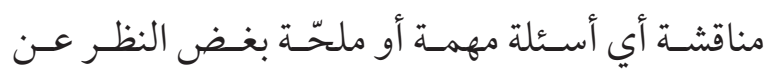

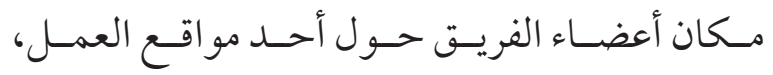
حيـث يمكــن الاجتــاع في بيئسة افتراضيـة تمثـل هــا

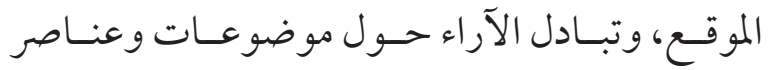

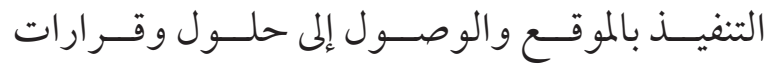
تشــار كية متفـتق عليهـا (Zhang and Chen, 2019) . مـع أهميـة اعتبــار التطــور والتنـوع الحــادث في البيئـات الافتراضيـة وتطـور اسـتخدامها كإحـدى إنى

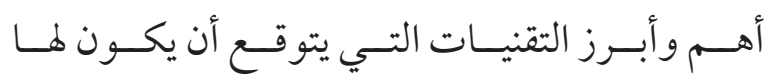
مستقبل واعـــ في دعـم التعليـم و التصميــم المعـاري

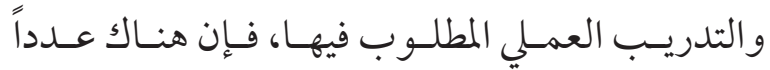

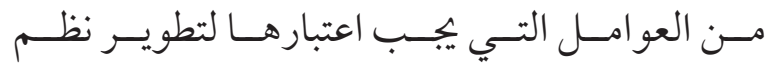

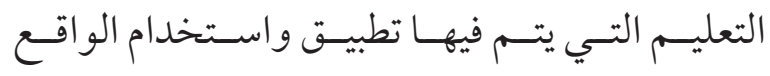

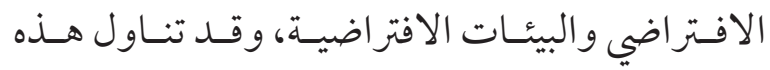
الاعتبــارات (Kavanagh., et al. 2017) في دراســة متعمقــة لاسـتخدام تقنيـات الواقــع الافـتر اضي في

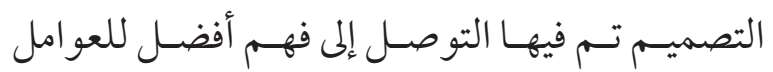

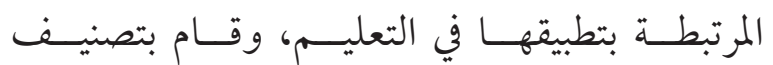

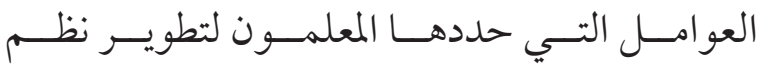




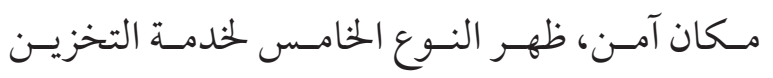

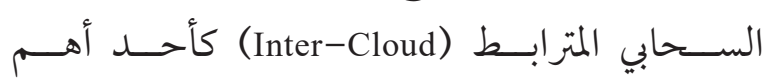

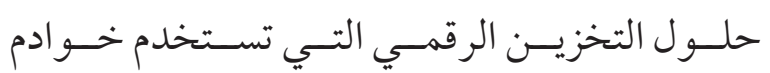

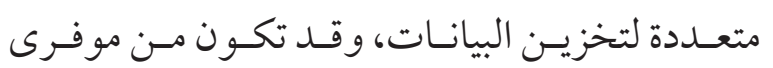

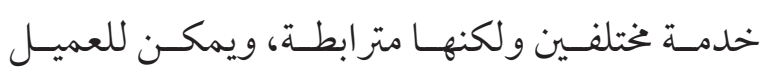

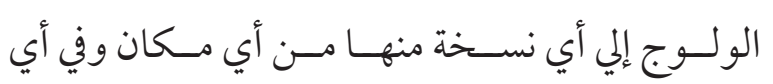

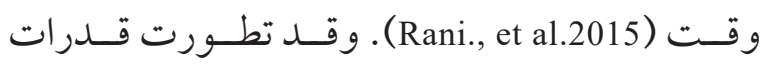

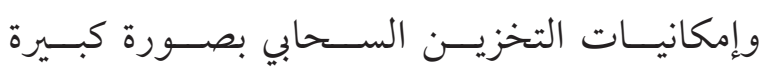

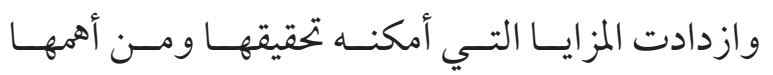

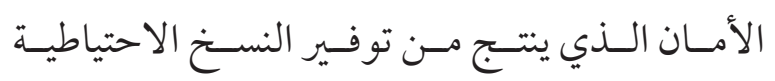

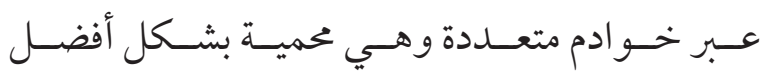

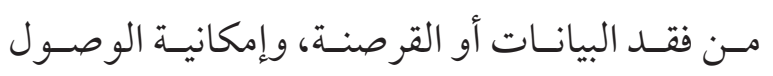

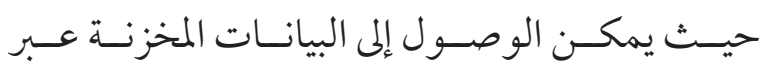

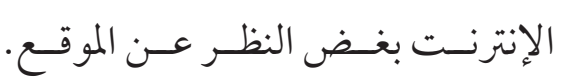
ومـن ناحيـة خدمــة التخزيــن السـحابي فيتـم

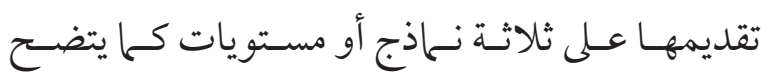

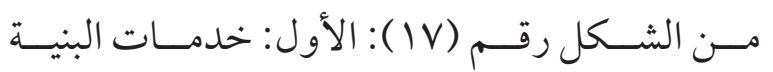

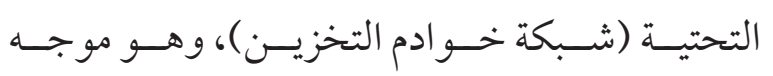

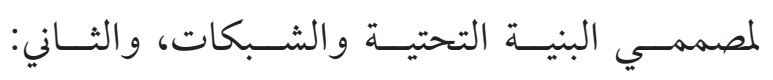

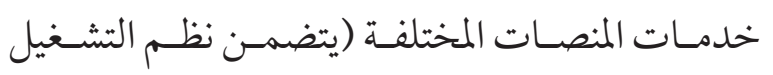

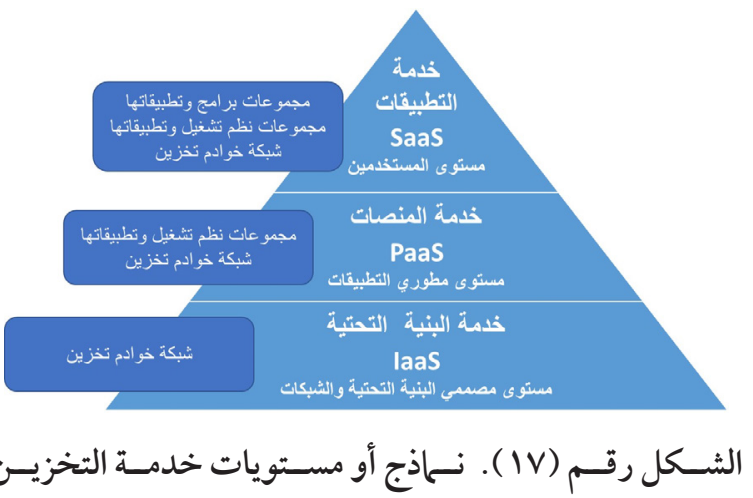

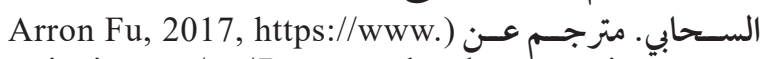
uniprint.net/en/7-types-cloud-computing-struc(/tures
إلى البرامـــ في مــكان و احسـد ويمكــن اسـتخدامها

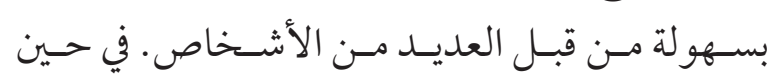

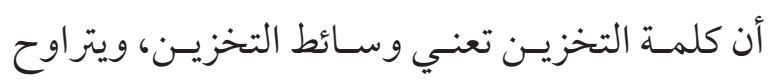

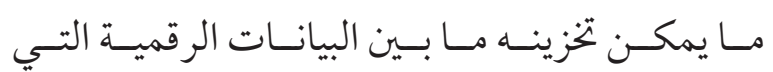

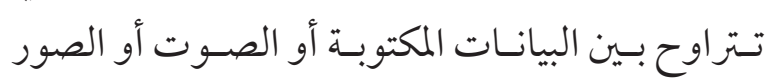

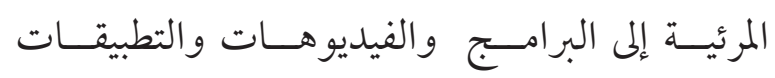

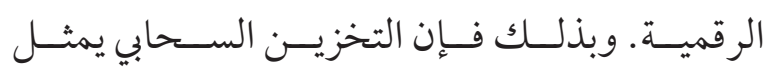

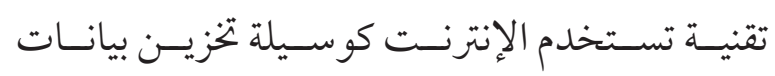
رقميـة، ويمكــن تطبيقهــاعـلى أربعــة مســتويات:

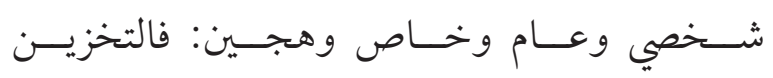

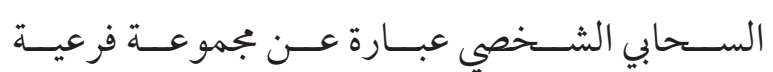

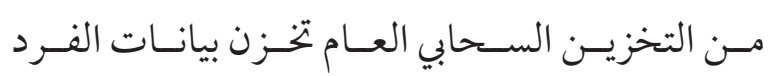

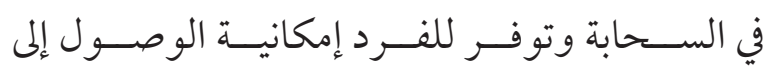

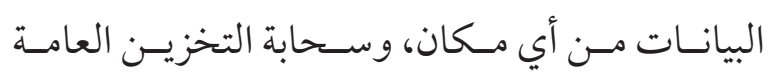

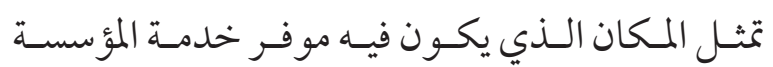

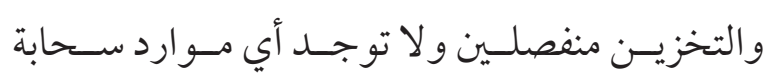

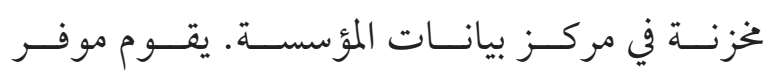

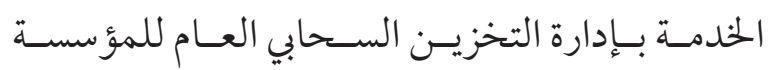

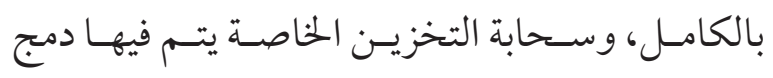

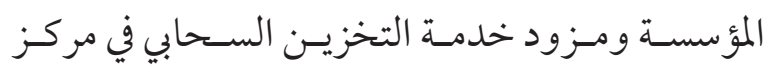

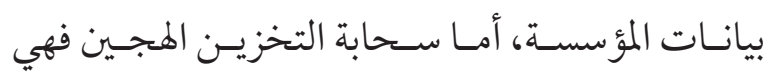

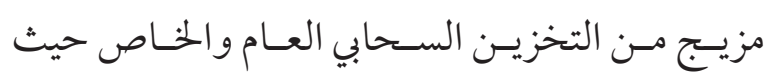

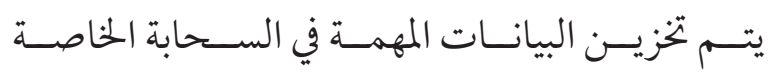

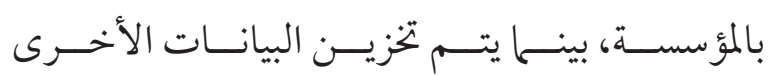

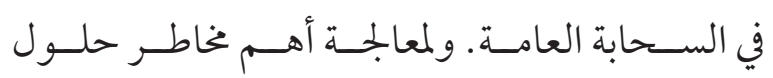

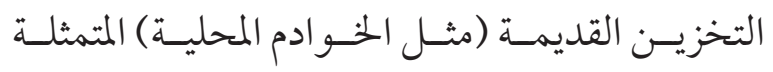

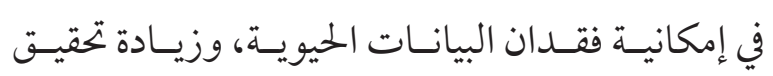

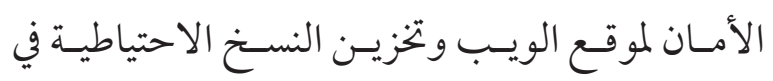


المستخخدم، وبـطء التحميـل، وكسر الانغـلمار وتجميد

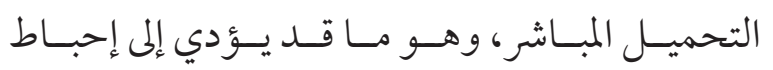

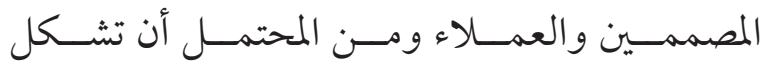

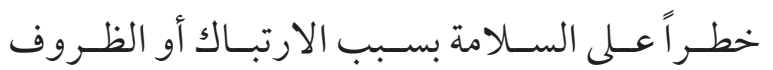

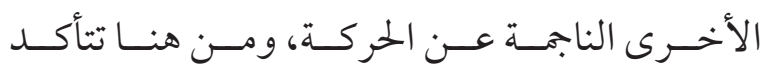

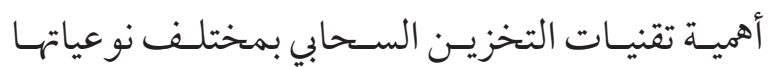

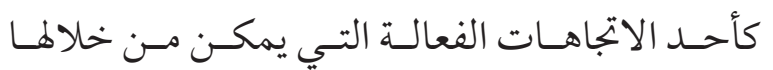
معالجــة هـــهـ الإشـكالية (Huawei, 2017b).

\section{r. التحديات التي تواجه تطبيق تقنيات الواقع}

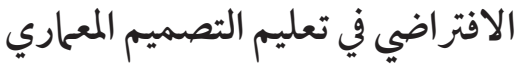

أظهــرت مر اجعــة الأدبيــات ذات العلاقــة

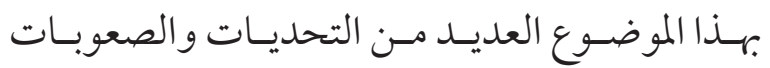

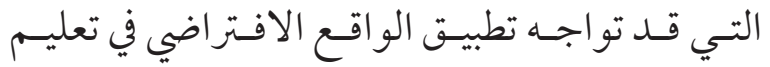

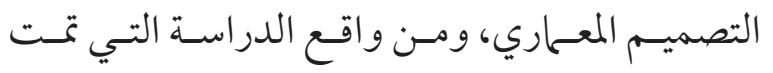

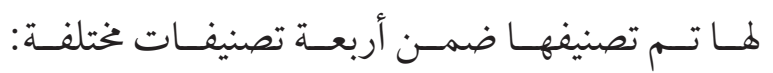

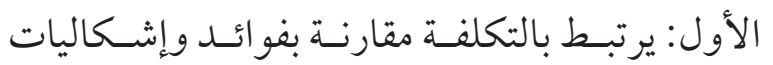

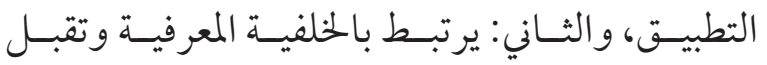

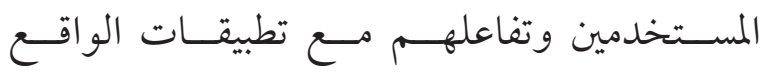

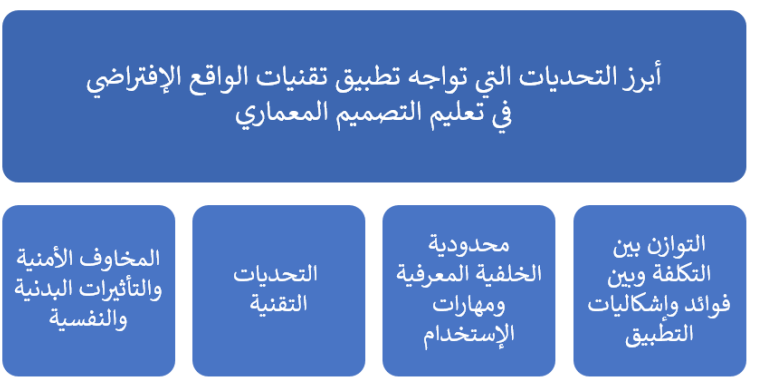

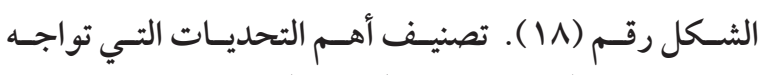
تطبيـق تقنيـات الواقـع الافتراضي التحاني

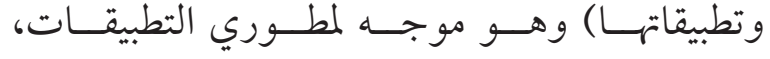

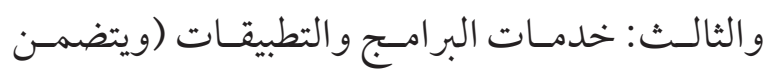

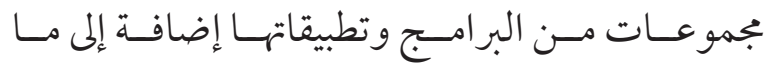

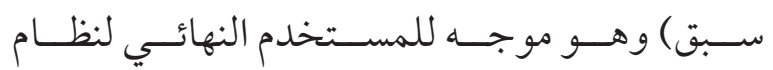
الحوســبة السـحابية (Fu, Arrow, 2017).

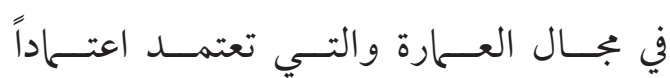

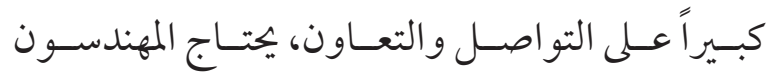

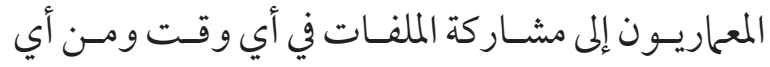

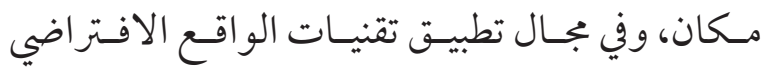

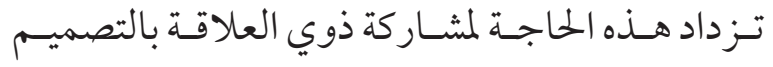

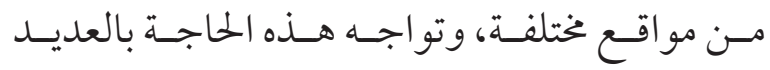

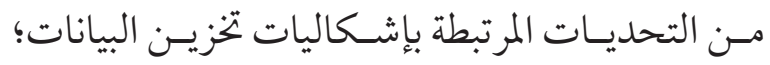

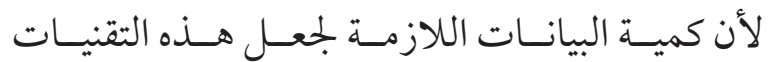

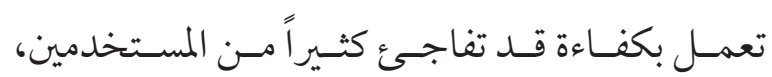

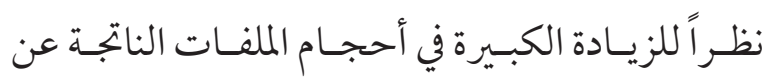

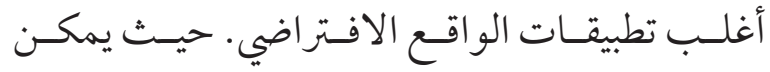

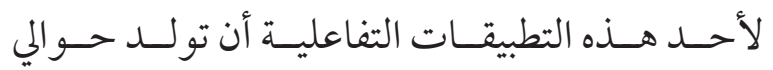

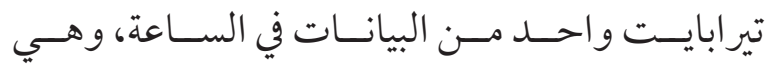

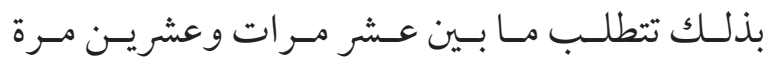

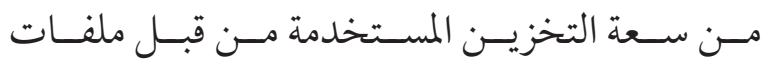

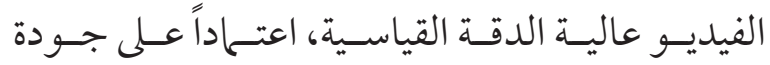

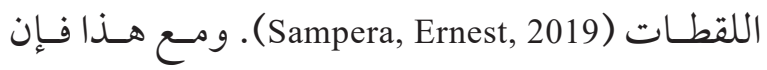
تحقيـق الاسـتفادة المطلوبــة عنـــ اسـتخدام تطبيقـات

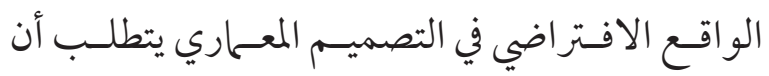

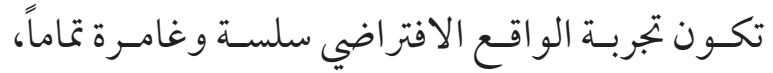

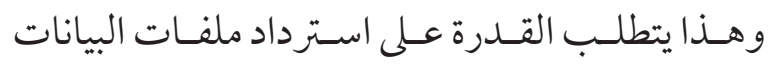

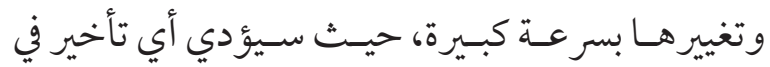

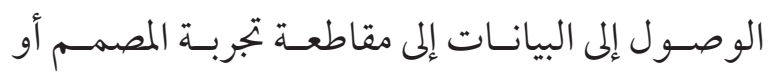


وبذلـك فـإن تطبيـق هـــه التقنيـات في المجــال

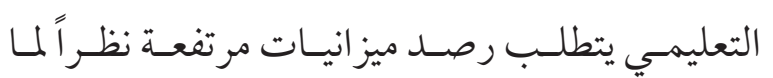

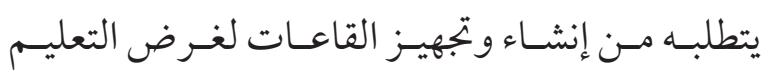

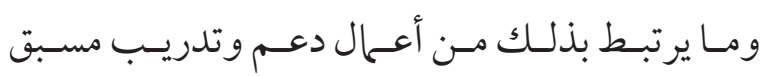

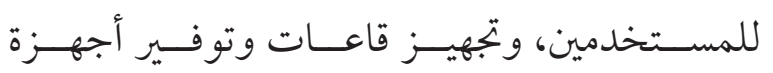

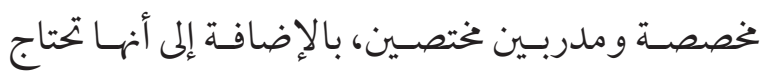

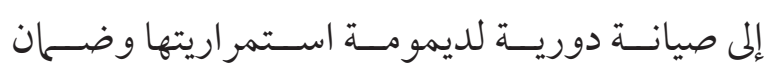

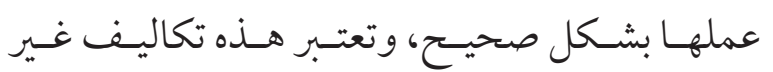

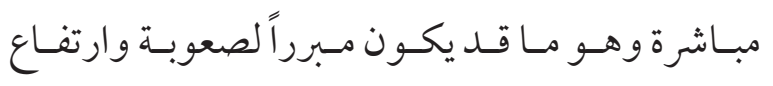

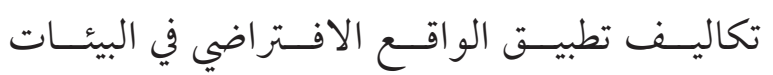

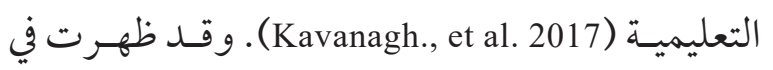

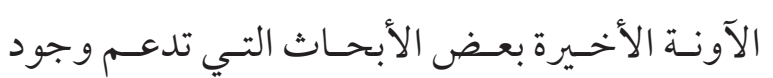

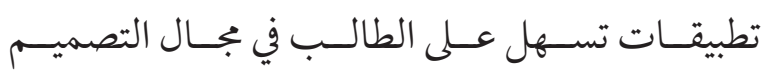

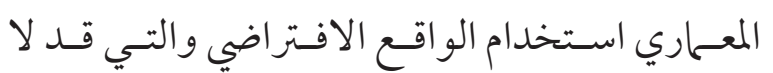

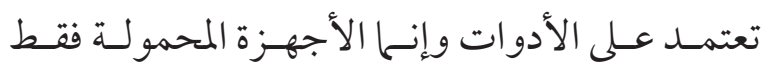

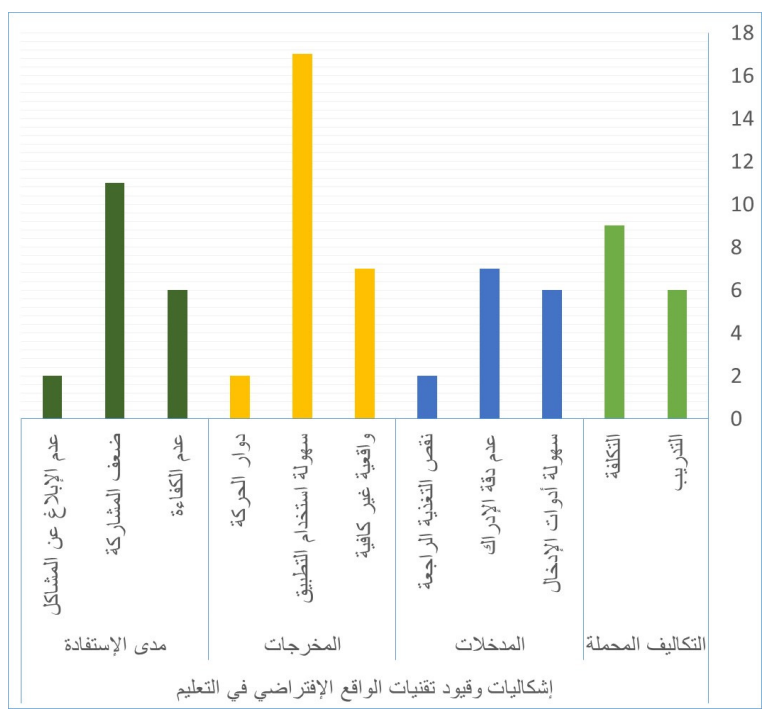

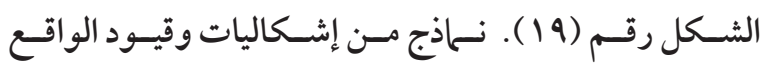

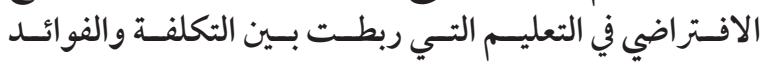

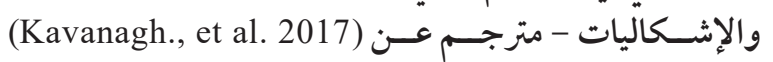

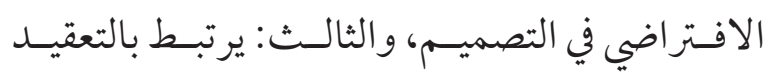

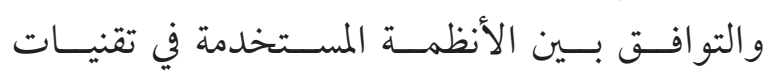

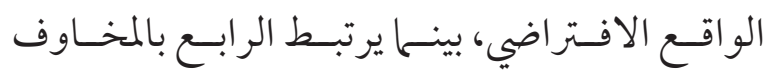

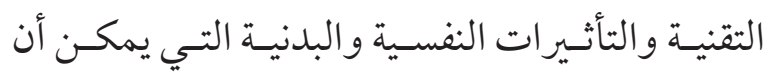
تنتـج عـن اسـتخدام هـــه التقنيـات.

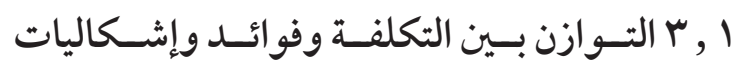
التطبيـق

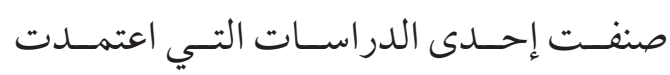

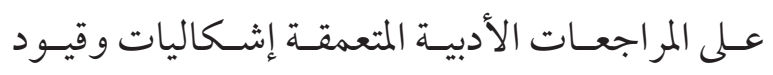

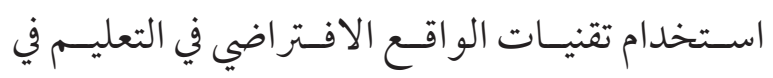

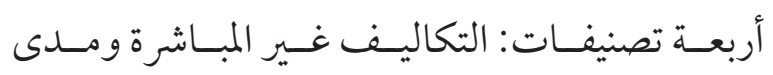

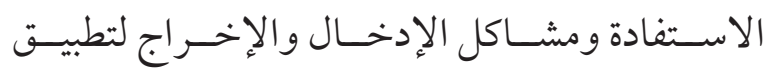

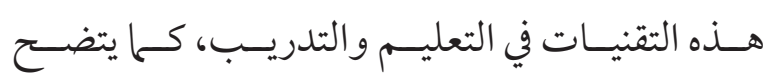
مـن الشـكل رقــم (19).

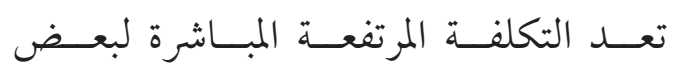

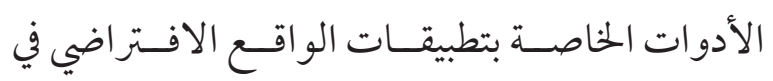

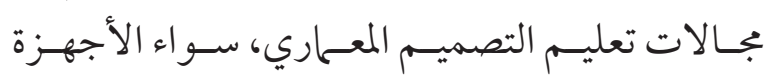

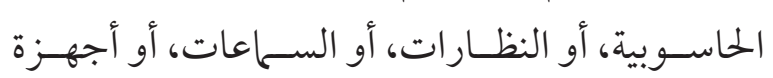

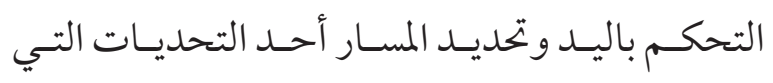

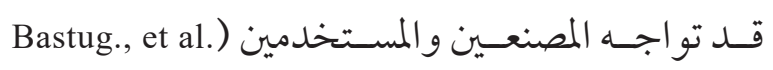
2017)، فالـشر كات المصنعـة تو اجـهـ تكلفــة الإنتـاج

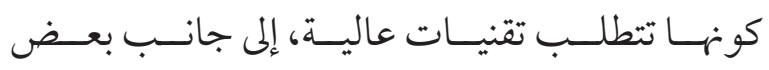

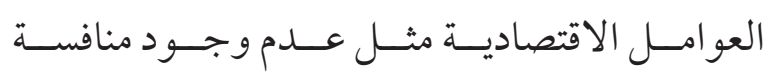

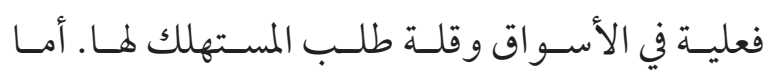

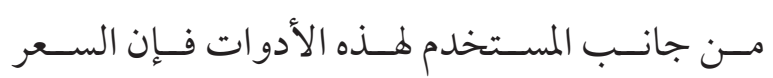

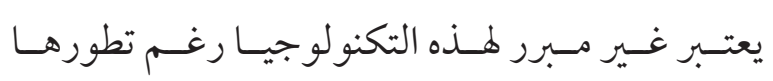
وعسدم وجــود خيـارات مختلفــة للميزانيـة. 


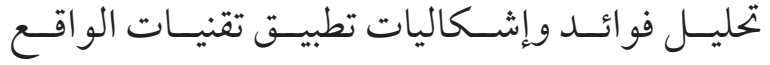

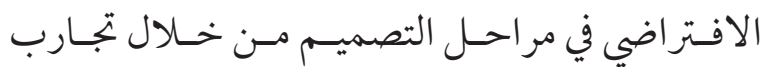

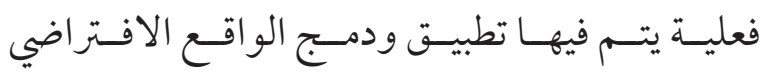

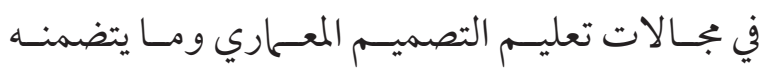

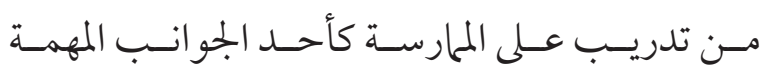

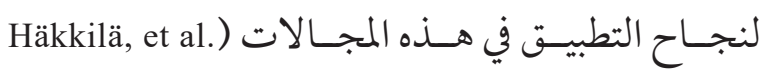

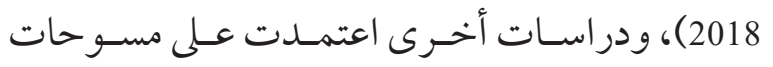

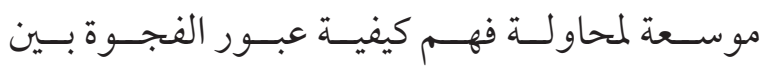

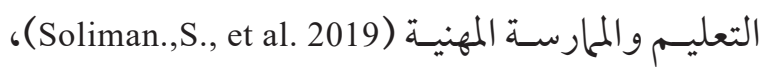

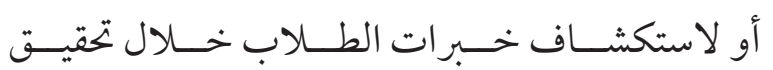

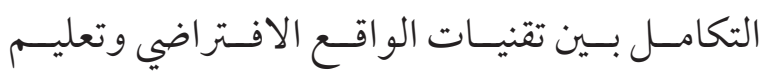
التصميــم المعسماري (Williams., et al. 2019)، أو توني

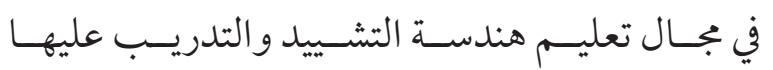
(Wang., et al. 2018)

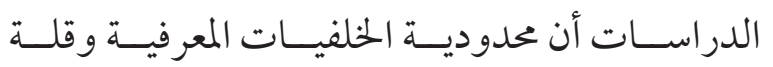

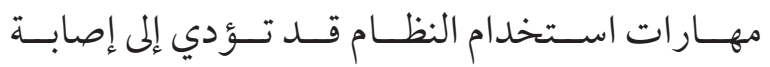

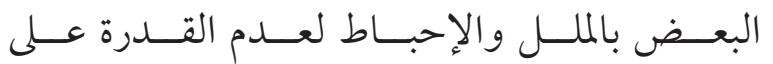

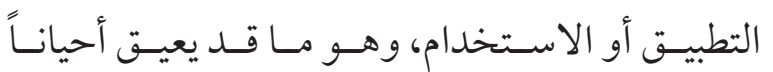

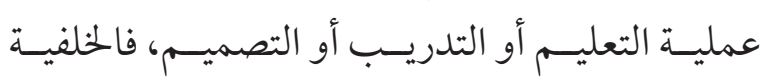

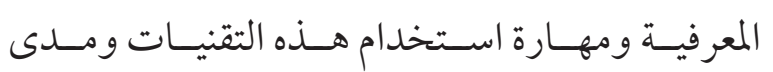

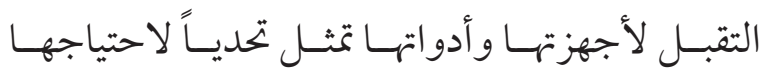
إلى تهيئسة وتوعيـة وتجهيـز وتدريـبـ مســبـ. وبالنظـر إلى طبيعـة تقنيـات الو اقـع الافتراضي

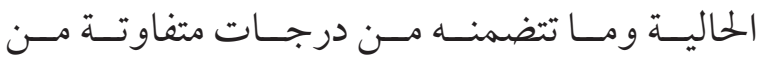

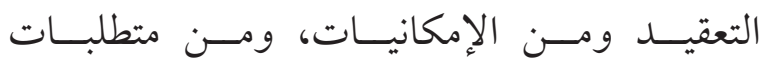

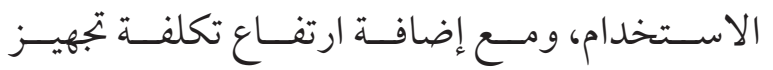

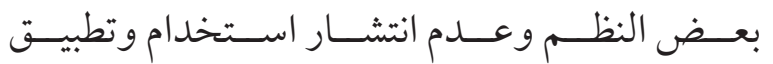

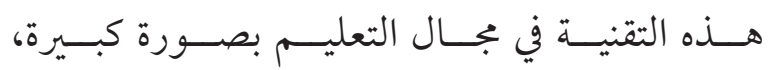

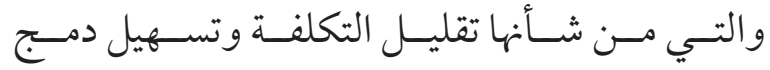
الواقـع الافـتراضي بالعمليـة التصميميـة و التعليميـة.

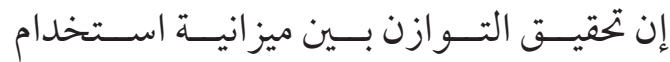

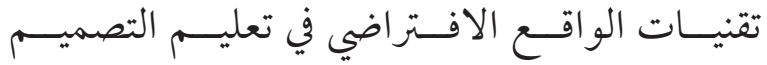

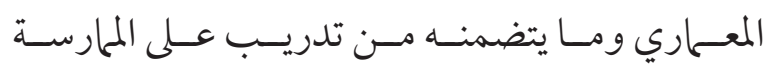

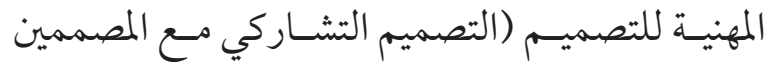

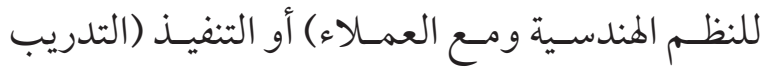

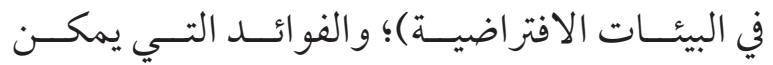

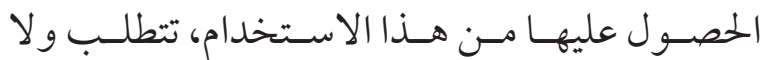

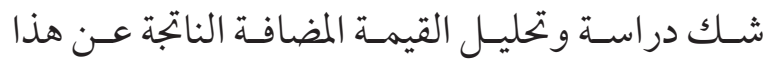
الاسـتخدام مقابـل التكلفــة المبـاشرة وغـير المبــاشرة

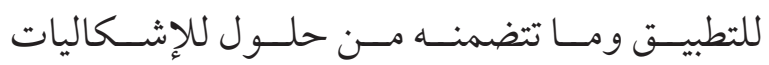
والتحديـات المتوقتـع حدوثهــا.

\section{r r, r r محدوديـة الخلفيـة المعرفيـة ومهــارات}

الاسـتخدام

يعتـبر ضعـف الخلفيــة المعرفيسة ومهـــارات

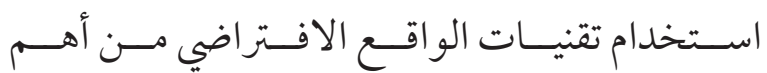

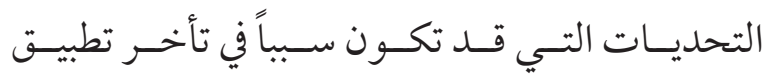

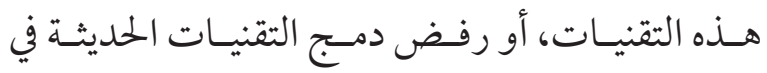

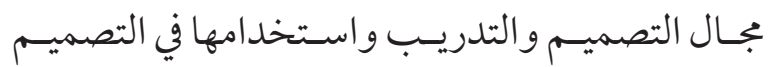

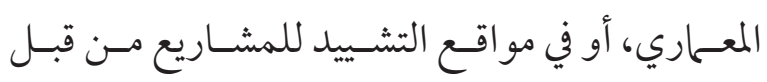

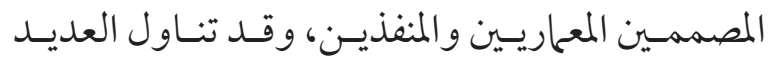

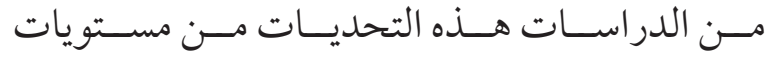
وجو انـب مختلفـة: فبعضهـا تناولـه مـن منظـور تأثـير

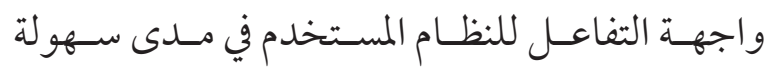

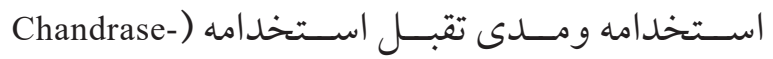
kera and Yoon. 2018 وبعضهـا تناولـه مسن منظـور 


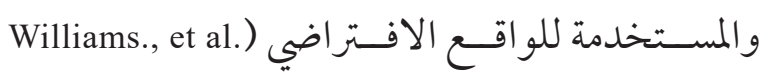

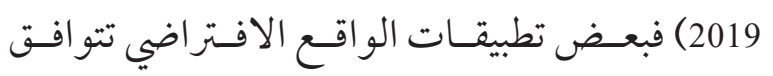

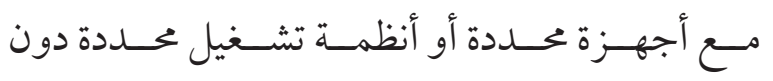

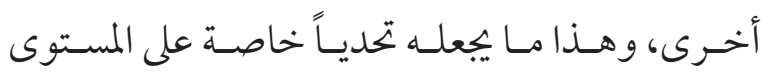

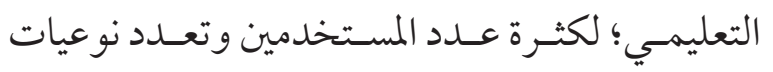

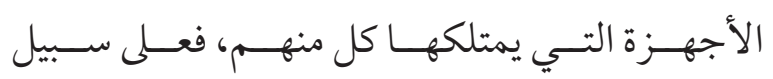

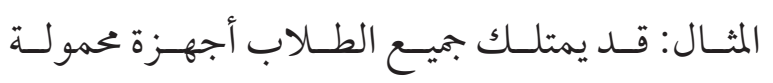

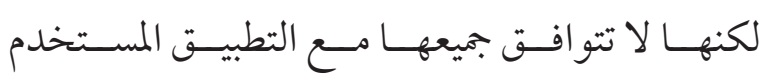

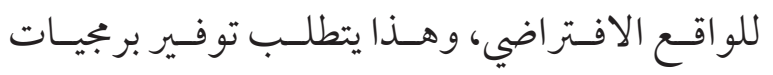
خاصـة أو تغيـير التطبيـق لتحقيـق التوافـق المطلـوبـ.

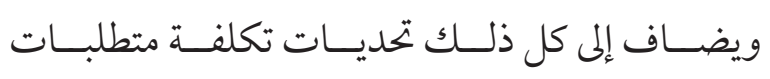
التخزيــن للبيانـات الخاصـة بهـــه التقنيــات، سـو اء

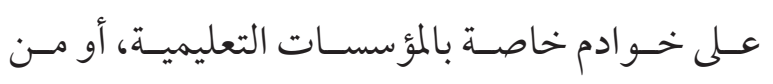

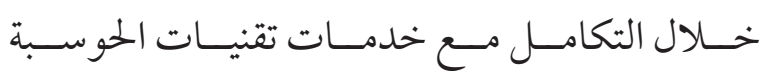
السـحابية التـي سـبق الإشـارة إليهـا.

\section{ع , ب المخــاوف الأمنيــة والتأثــــرات البدنيــة}

و النفسـية

تمثـل المخــاوف الأمنيـة أحســ التحديـات التي

ترتبـــ بأغلــب التقنيــات الرقميـــة عمو مـــاً مثــل :

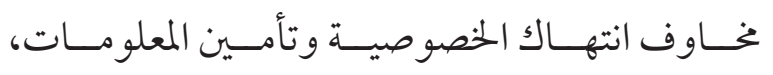
وخــاوف متطلبـات تخزيـن بيانـات الواقـع الافتر اضي

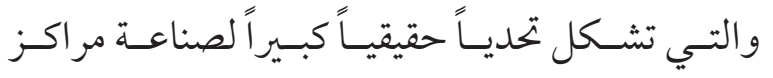

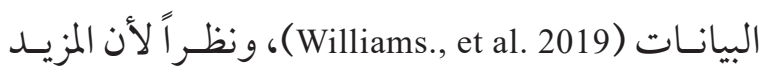
مــن الـشر كات تطـرح تطبيقـات الواقــع الافـتراضي

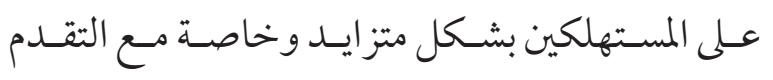

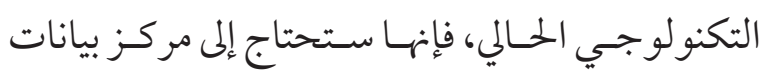

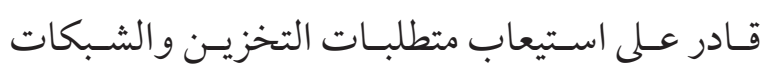

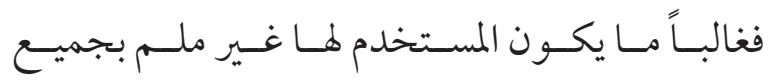

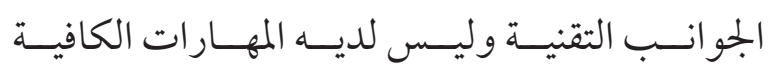

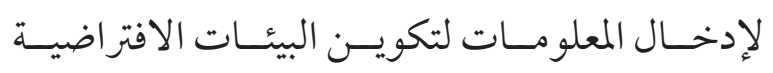
بصـورة كاملـة أو صحيحـة، وهـذا يؤكـــ عـلى أهميـة

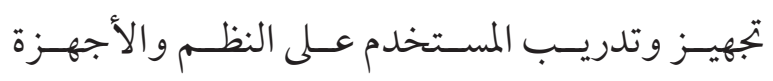

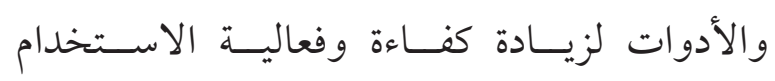

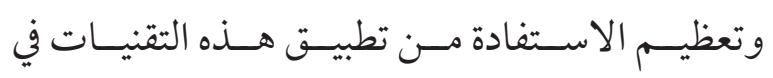
التعليــم (Kavanagh., et al. 2017) و (7) Velev, D., and .(Zlateva, P., 2017

\section{r ب التحديات التقنية}

تواجـــه التقنيــات الحميثــة سريعــة التطــور

العديـــ مـن القيـود التقنيـة التـي تمثـل تحديـاً رئيسـاً

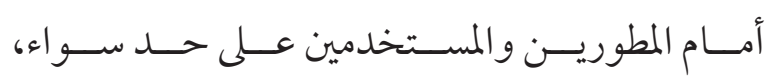
وأظهر ت إحــدى الدر اسـات أهميـة اعتبـار التقنيـات المسـتخدمة للفــروق بــين الجنســين والطبيعــة

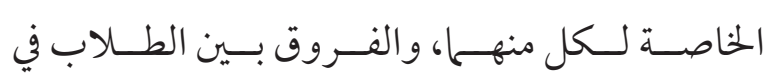

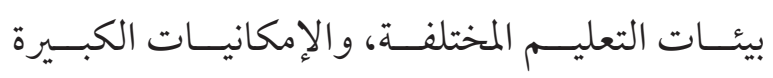

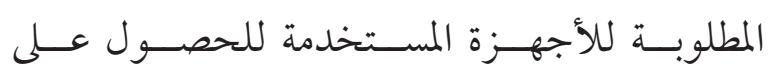

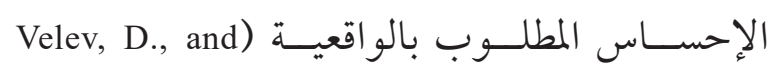

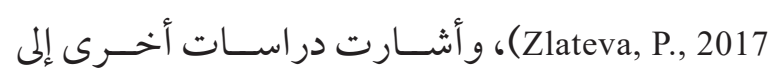

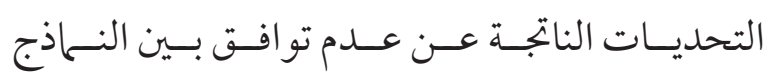

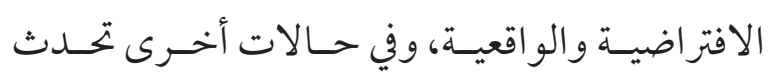
إشـكاليات تقنيـة في محـاكاة التصاميسم المعحاريـة لحـل

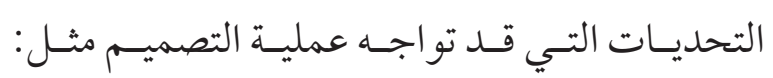

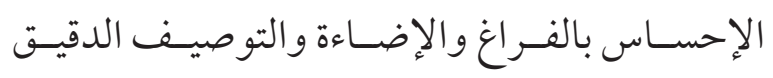

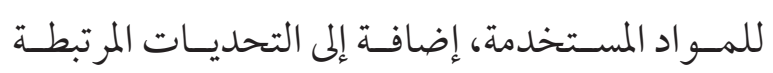

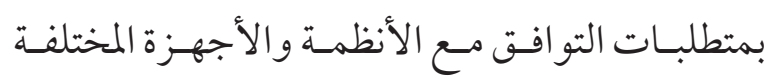




\section{ع ـ النتائج والمناقشة}

مـع تطـور تقنيـات الواقـع الافتراضي وتنــوع البيئـات الافتر اضيـة التـي تـم استكشـافها وتصنيفهـا

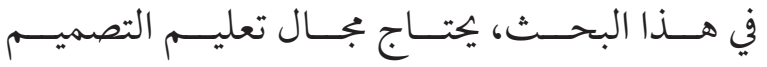
المعـلماري إلى مو اكبـة التطـور ات التكنولو جيـة الحديثـة

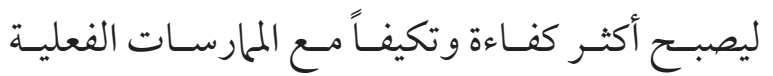

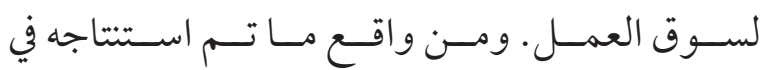

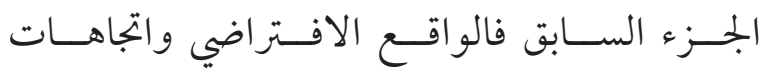

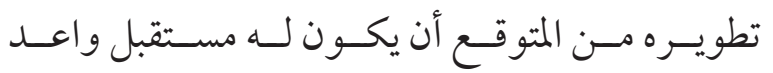

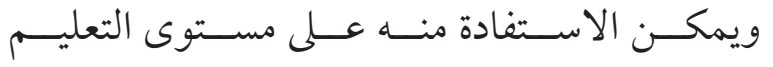

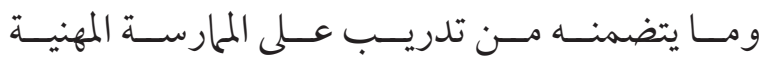

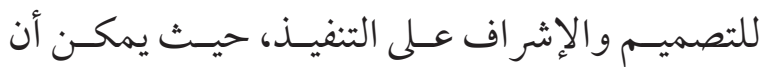

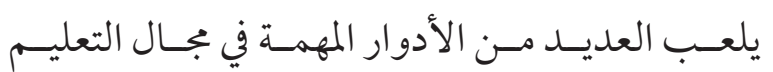
و التدريسبـب والملمارسـة المهنيـة:

فقــي جــال التعليــم يجــب تطويـر الأسـاليب التعليميـة المتمدحـورة حــول المعلـم و الطالـبـ، إلى بيئة

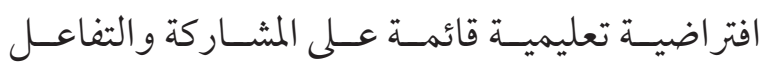

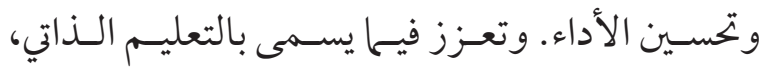

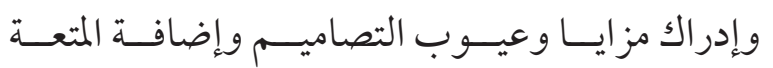
والتفاعــل والمشـــاركة بــين المســتخدمين؛ لتحقيـتق

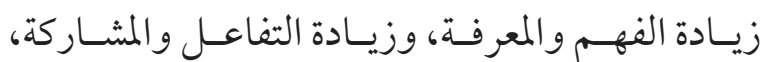

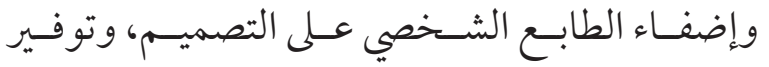

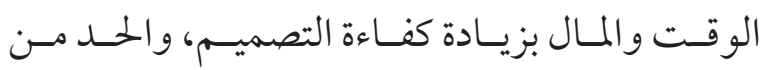
الفجـوة بــين التعليــم والملمارسـة المهنيـة.

وفي ججــال التدريــبـ عـلى الملمارســة المهنيــة للتصميـم مـن خـلال لبيئـات الافتراضيـة، وهـو مــا يجهــز الطالـب لمجــال الممارسـة المهنيـة بدعـم التواصل
الهائلــة التــي سـتضعها بيانـات الواقـع الافـتراضي

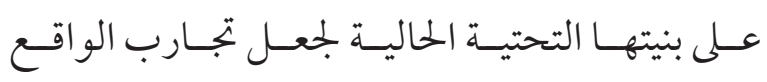

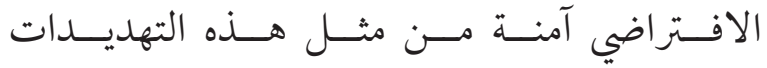

.(Bastug., et al. 2017)

يضــاف إلى مــا ســبق عــدد مــن التحديــات التسي تم التركيـز عليهــا بصـور متفاوتة في الدراسـات

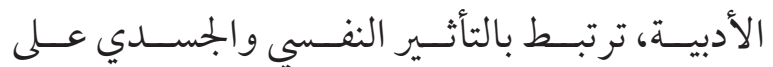

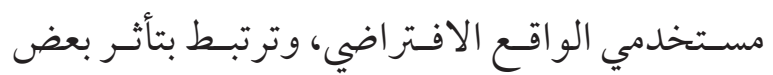

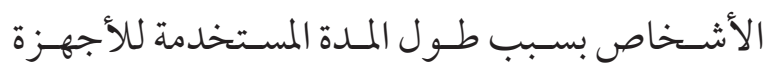

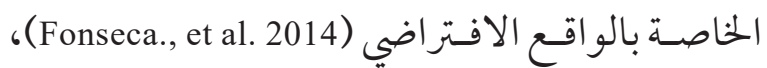

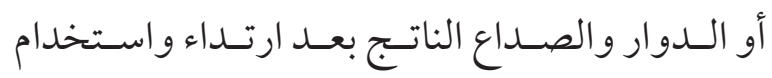
Sun., et al.) نظارات وسـاعات الـر أس لــدة طويلـة 2019)، والـذي يكــــن نتيجـة لاختـالاف الإشـار ات

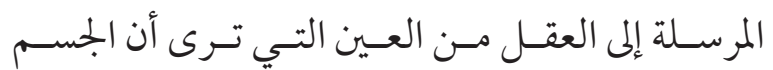
يتحـــرك عنـــد التجــول في الواقــع الافـتر اضي، بينـــا

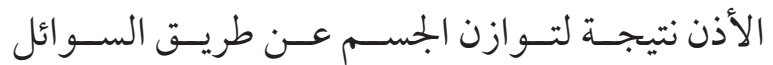

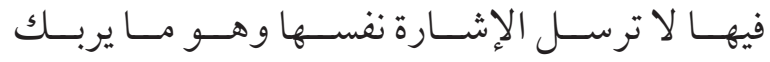
العقـل ويسـبب عـدم الارتيــاح والغثيـان والإغــاء،

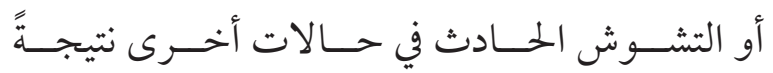

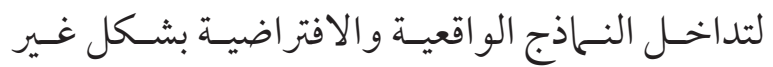

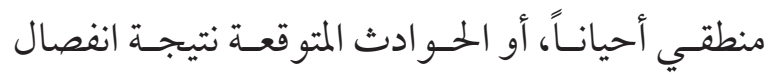

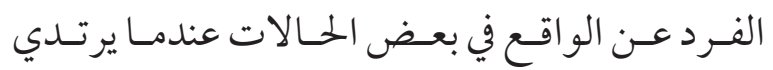

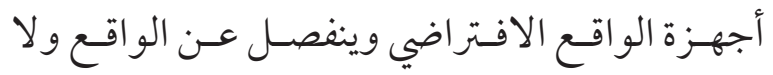

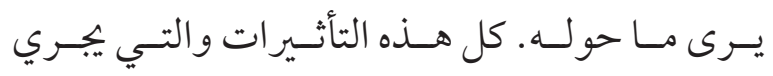

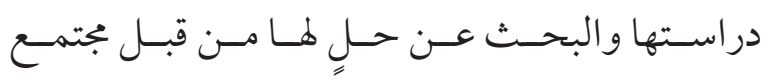
البحـث العلمسي لعلـوم الحاسـبـ والصحسـة النفسـية .(Cook. et al. 2019) 
مسن واقــع مــا تــم استكشــافه للاتجاهــات

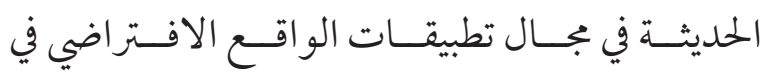

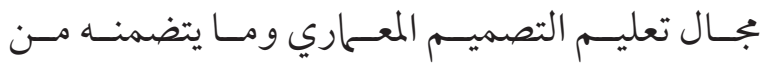
تدريسب عـلى الممارسـة المهنيـة في التصميـم (التصميـم

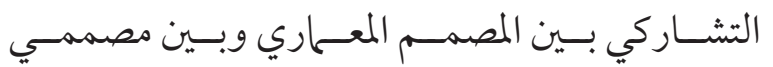
النظــم الهندسـية وبـين المصمـــم المعـلماري والعميـل أو مالـك المـشروع)، وفي مجـال الإشر اف عـلى التنفيــ (البيئـات الافتر اضيـة للتدريـبـ) و التحديــات التسي

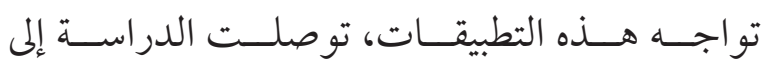
التـالي:

أهــــم وأبـــرز الاتجاهـــات الحديثــة لتقنيــات الواقـع الافــتراضي في جـــال التصميــم المعـــاري

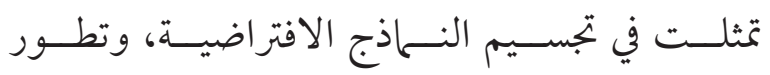
وتنــوع البيئــات الافتراضيــة وتطـــور اســتخدامها

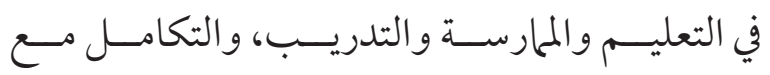
تقنيــات الحوســــة الســـابية.

أهـــم وأبــرز التحديــات التــي تو اجــه تطبيـق

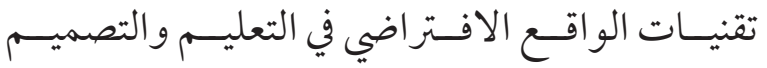

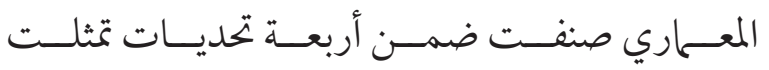

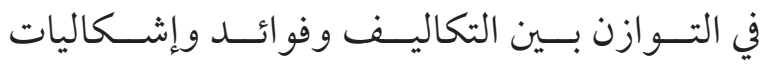
التطبيـق، ومحدوديــة الخلفيــات المعرفيـة ومهــارات الاسـتخدام، والتحديــات التقنيـة، والمتخــاوف

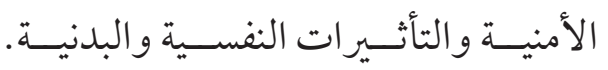
وبذلـك يتضـح أن لدينـا محوريـن متعارضـين:

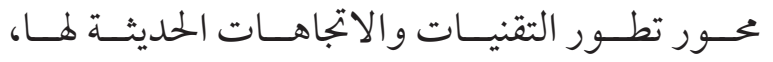

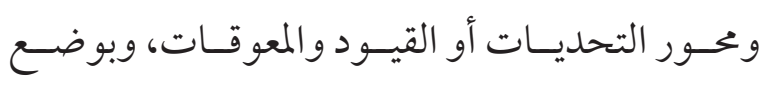
هذيــن المحوريسـن في مصفوفــة نطلــت عليهـا
حـول الأفـكار واستكشـاف الآراء المختلفـة وتقييمها بالوقـت نفسـه، وتقديـم تصـور واضـح للمسـتفيدين عـن التصميــم المقـترح مــن خــلال بيئـات افتر اضيـة متعـــددة الخصائــص تســمح بمشـــار كة التصميـــم وتبــادل الخــبرات ومشــاركة العمــلاء في العمليــة التصميمــة للمشــاريع قبـل التنفيــ وهــو مـا يسـمح هـــم بتطويرهــا بشـكل أفضـل.

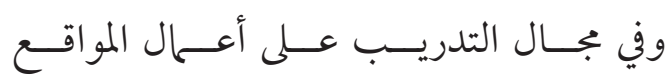

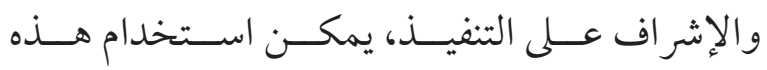

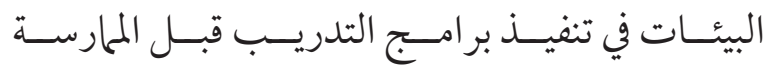

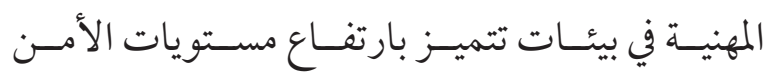

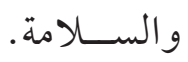

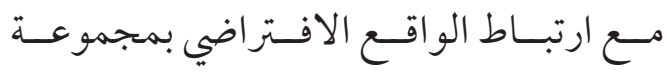

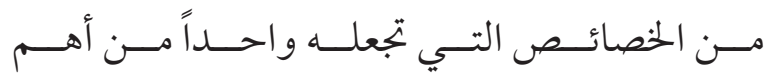
التقنيــات الرقميــة الداعمــة للتصميــم المعـــاري و التعليـم لكونـهـ يوفــر بيئـة افتر اضيـة مرنـة تسـمحح

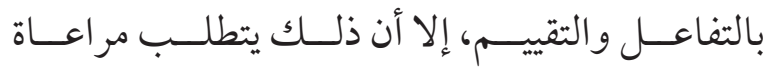

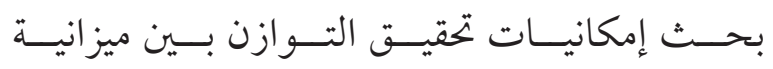
اســتخدام تقنيــات الواقـــع الافــتراضي في تعليــم

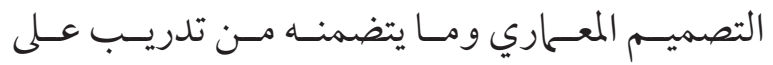

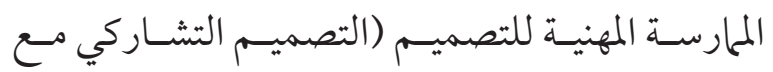

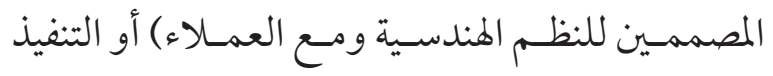

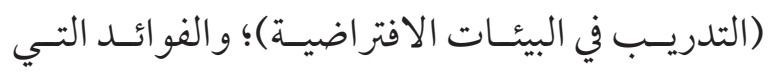

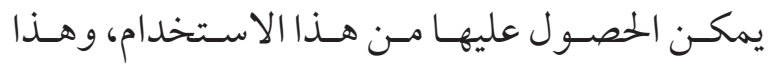
مــن ثـــم يتطلــب دراســة وتحليـل القيمــة المضافــة

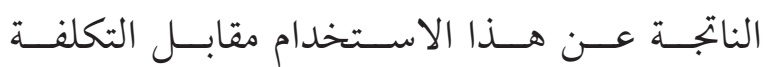

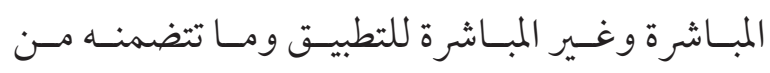
حلـول للإشـكاليات والتحديـات المتوقـع حدوثهــا. 
والمختصـين والمعلمسين والطـلاب والمارسـين

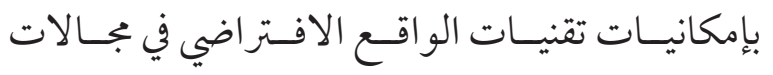
كل منهــم، ودراسـة التحديـات التـي تــم اسـتنتاجها وبحــث إمكانيـات التغلـب عليهـا أو تقليـل تأثيرهـا.

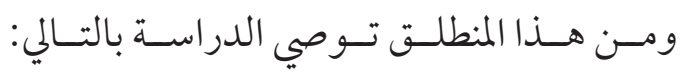
عـلى الباحثـين إجـــراء مزيد مـن الدراسـات في

محوريـن: الأول يبحـث مصفوفــة العلاقـة بـين محساور

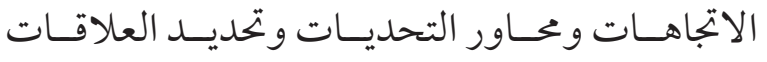

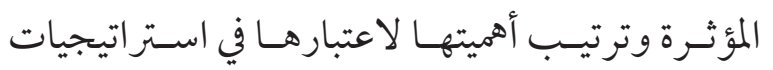

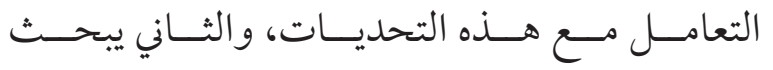

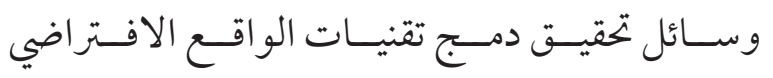

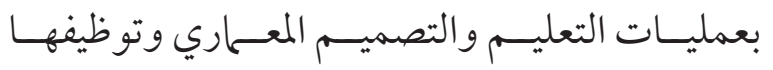

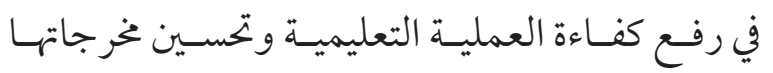
وســ الفجـوة بـين تعليـم تصميـم و الملمارسـة المهنيـة.

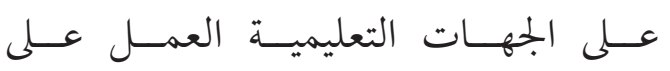

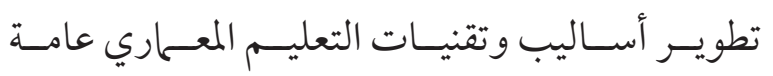

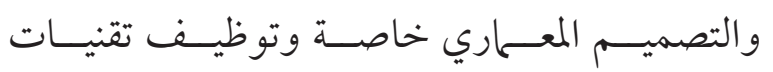

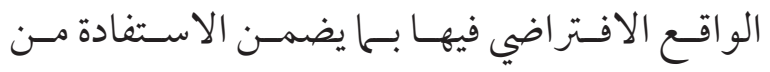

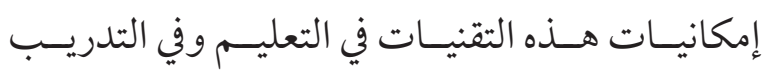

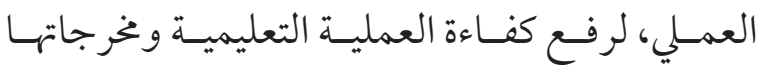

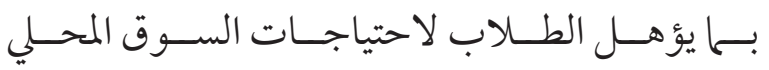

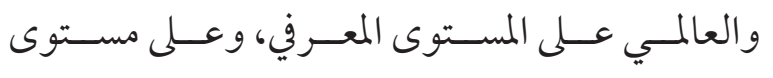

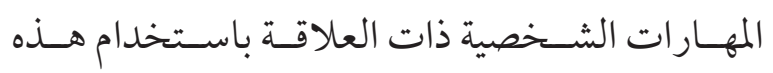

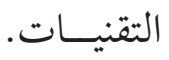

عسلى الـشر كات المتخصصـة توفـير تطبيقـات

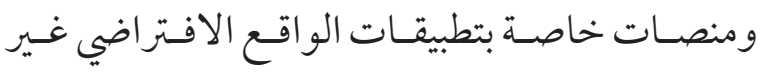

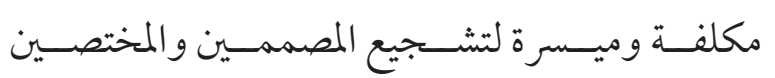

(المصفوفــة اتجاهــات وتحديــات تطبيـق تقنيــات

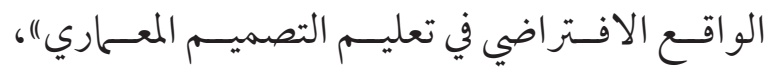

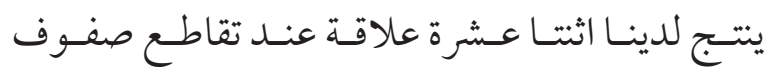

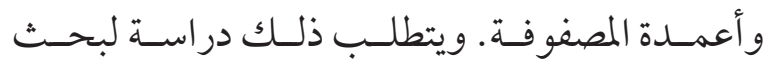

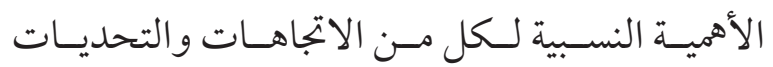

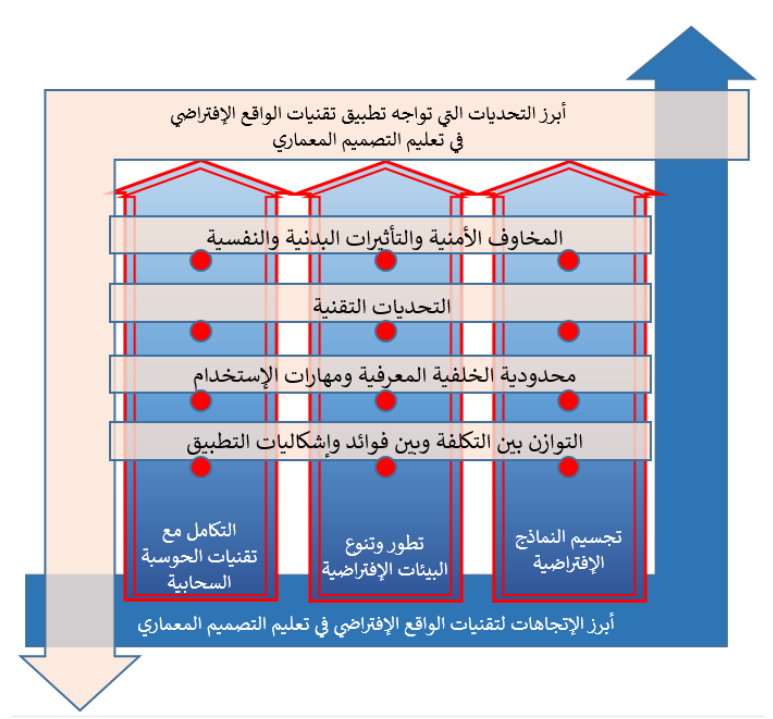

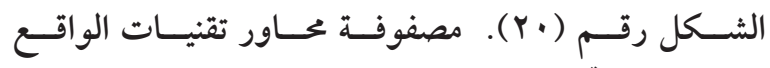

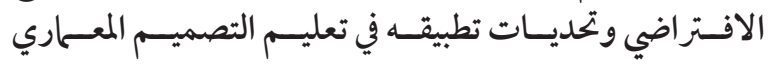

عنــد تطبيـق تقنيــات الو اقـع الافـتراضي في بيئـات التعليـم المختلفــة في ظروفهـا وإمكانياتهـا وســــاقاتها

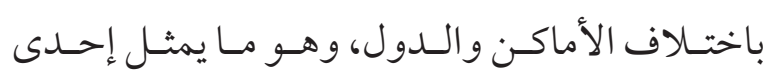

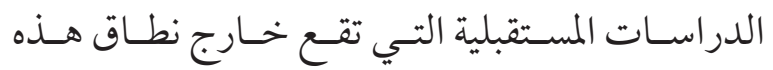
الدراسـة، وتـوصي بأهميـة إجرائهـا.

هـ التوصيات والرؤى المستقبلية

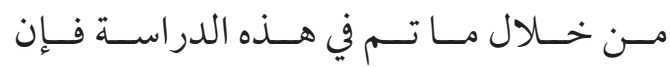

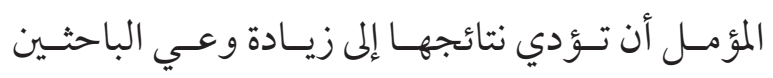




$$
\text { شياء إبر اهيم الكبسي؛ أحمد عمر محمد سيد مصطفى: اتجاهات وتحديات الو اقع الافتراضي في تعليم التصميم المعهاري. }
$$

"Augmented Reality, Virtual Reality and their effect on learning style in the creative design proces". Design and Technology Education Association, EJ1171588.

Cook, Matt., Lischer-Katz, Z., Hall, N., Hardesty, J., Johnson, J., McDonald, R., Carlisle, T., 2019. "Challenges and Strategies for Educational Virtual Reality: Results of an Expert-led Forum on 3D/VR Technologies across Academic Institutions". Information Technology \& Libraries. Dec, Vol. 38 Issue 4, p25-48. 24p. 1 Chart.

Cristea, Dragos., Navarro,R., Riquelme, J., Ivanov, M., Anwar, M., Suciu, G. 2019. "Integrating IoT Modern Communication Architectures into the New Generation of VR/ MR Environments", Annals of "Dunarea de Jos" University of Galati, DOI https://doi. org/10.35219/eai1584040948.

Cruz-Benito, Juan., Maderuelo, C., Barcia-Penalvo, F., Theron, R., Perez-Blanco, J.,Zazo, H., Martin-Suarez, A. 2016. "A Software Architecture to Support Learning in Virtual Worlds". IEEE Revista Iberoamericana de Tecnologias del Aprendizaje. 11(3), 194-204. doi:10.1109/RITA..2589719.

Fonseca, David., Marti, N., Redondo, E., Navarro, I., Sanchez, A., 2014. "Relationship between student profile, tool use, participation, and academic performance with the use of Augmented Reality technology for visualized architecture models". Computers in $\mathrm{Hu}-$ man Behavior 31, 434-445.

Häkkilä, J., Colley, A., Yliharju, A. 2018. “Introducing Virtual Reality Technologies to Design Education". ResearchGate, Article May.

HUAWEI Technologies, ILabs, 2017a."Cloud VR Bearer Network", https://www-file.huawei. com/-/media/corporate/pdf/ilab/cloud vr oriented bearer network white paper en v2.pdf

HUAWEI Technologies, XLabs Wireless, ABI research, 2017b."Preparing for a cloud AR/ VR Future" - Augmented and virtual reality: peering into the future", https://www.huawei.com/en/industry-insights/outlook/mobile-broadband/xlabs/insights-whitepapers/ cloud-vr-ar-white-paper
بمجــال التصميــم المعــاري، بمــن فيهـــم المعلمـون

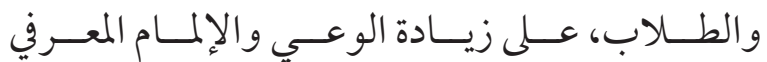

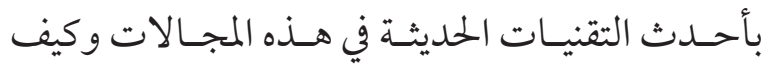
يمكــن اسـتخدامهاو التدريسب عليهـا.

عـلى الـشركات المطــورة لتقنيـات وتطبيقـات الواقـع الافـتر اضي زيــادة اسـتثماراتها في تطويـر هـــهـ

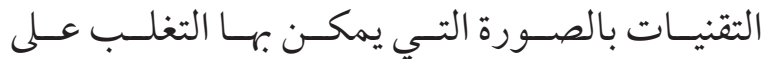

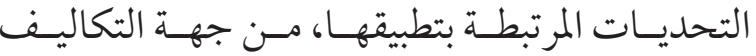

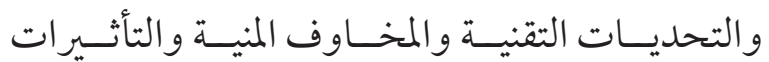
البدنيـة و النفسـية الناتجـة عــن اسـتخدامها؛ لضـــان سرعة انتشـارها و التوسـع في اسـتخدامها و الاسـتفادة

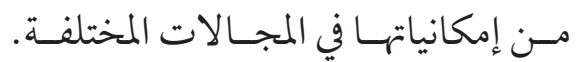

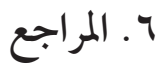

\section{English References}

Alizadehsalehi, s., Hadavi, A., Huang, J. 2019. "Virtual Reality for Design and Construction Education Environment" .ResearchGate. April.

Bahri, Haythem ., Kromarik, D., Moezzi, R., Koci, J. 2019. "Efficient Use of Mixed Reality for BIM system using Microsoft HoloLens". IFAC Conference on Programmable Devices and Embedded Systems PDES, IFAC PapersOnLine 2019 52(27):235-239.

Bashabsheh, A., Alzoubi, H., Ali, M. 2019. "The application of virtual reality technology in architectural pedagogy for building constructions". Alexandria Engineering Journal, 58, 713-723.

Bastug, Ejder., Bennis, M., Medard,M., Debbah, M., 2017. "Towards Interconnected Virtual Reality:Opportunities, Challenges and Enablers".Draft, arXiv:1611.05356v2 [cs.NI] 24 Mar.

Chandrasekera, Tilanka., Yoon, So-Yeon. 2018. 
Noghabaei, Mojtaba., Heydarian, A., Balali, V., Han, K. 2020. "Trend Analysis on Adoption of Virtual and Augmented Reality in the Architecture, Engineering, and Construction Industry". Received: 25 December 2019; Accepted: March.

Olshannikova , Ekaterina., Ometov, A., Koucheryavy, Y., Olsson, T., 2015. "Visualizing Big Data with augmented and virtual reality: challenges and research agenda". Journal of Big Data 2-22.

Pamungkas, L., Meytasar, C., Trieddiantoro., H. 2018. "Virtual Reality As A Spatial Experience For Architecture Design: A Study of Effectiveness for Architecture Students". SHS Web of Conferences 41, 05005.

Rani, B. Kezia, Rani, B.P., Babu, A.V., 2015. "Cloud Computing and Inter-Clouds - Types, Topologies and Research Issues.". 2nd International Symposium on Big Data and Cloud Computing (ISBCC'15), Procedia Computer Science 50 ( 2015 ) $24-29$.

Sanchez-Sepulveda, Monica., Torres-Kompen, R., Fonseca, D. 2019. "Methodologies of Learning Served by Virtual Reality: A Case Study in Urban Interventions". Applied Sciences. 28 November. 9, 5161.

Shi, Yangming., Du, J., Ahn, C., Ragan, E., 2019 "Impact assessment of reinforced learning methods on construction workers' fall risk behavior using virtual reality". Automation in Construction, Volume 104, August, Pages 197-214.

Soliman, S., Taha, D., ElSayad, Z. 2019. “Architectural education in the digital age Computer applications: Between academia and practice". Alexandria Engineering Journal, 58, 809-818.

Sun, H., Li, Y., Paik, J. 2019. “Application of VR Technology in the Optimization Modeling of Port Wave-proof Building". Journal of Coastal Research. SI, 97, 267-272.

Sun, CH., Hu, W., Xu,D. 2019. "Navigation modes, operation methods, observation scales and background options in UI design for high learning performance in VR-based architectural applications". Journal of Computational Design and Engineering 6. 189196.
Huang, Y., Shakya, S., Odeleye,T. 2019. “ Comparing the Functionality between Virtual Reality and Mixed Reality for Architecture and Construction Uses". Journal of Civil Engineering and Architecture (409-414 .

Kavanagh, Sam., Luxton-Reilly, A., Wuensche, B., Plimmer, B., 2017. "A systematic review of Virtual Reality in education. Themes in Science \& Technology Education". Themes in Science \& Technology Education, 10(2), 85-119.

Kharvari, Farzam., Hohl, Wolfgang. 2019. "The Role of Serious Gaming using Virtual Reality Applications for 3D Architectural Visualization”. IEEE, 978-1-7281-4540-2/19/\$31.

Klerk, Rui de., Duarte, A., Medeiros, D., Duarte, J., Jorge, J., Lopes, D., 2019. "Usability studies on building early stage architectural models in virtual reality". Automation in Construction, 103, 104-116.

Köehler,T., Münster, S., Schlenker, L. 2014. "Smart communities in virtual reality. A comparison of design approaches for academic education". Interaction Design and Architecture(s) Journal - IxD\&A, N.22, pp. 48-59.

Krietemeyer, B., Bartosh, A., Covington, L. 2019. "A shared realities workflow for interactive design using virtual reality and three-dimensional depth sensing". International Journal of Architectural Computing; Jun, Vol. 17 Issue 2, p220-235, 16p.ER.

Maghool, S., Moeini, S., Arefazar, Y. 2018. “ An Educational Application Based On VR Technology For Learning Architectural Details Challenges and Benefits". Archnet-IJAR, November - (246-272).

Milgram, P., Colquhoun, H. 1999. “A Taxonomy of Real and Virtual World Display Integration." Chapter 1 (1-16) in $\mathrm{Y}$ Ohta and $\mathrm{H}$ Tamura (Ed's), Mixed Reality - Merging Real and Virtual Worlds. Ohmsha (Tokyo) \& Springer Verlag (Berlin),

Milovanovic, Julie., Moreau, G., Siret, D., Miguet, F., 2017. "Virtual and Augmented Reality in Architectural Design and Education". An Immersive Multimodal Platform to Support Architectural Pedagogy. 17th International Conference, CAAD Futures. 


$$
\text { شياء إبر اهيم الكبسي؛ أحمد عمر محمد سيد مصطفى: اتجاهات وتحديات الو اقع الافتراضي في تعليم التصميم المعماري. }
$$

ty-changing-architects-world/, accessed in August, 2020

HMC Architects web site, Virtual Reality, https:// hmcarchitects.com/?s=Virtual+Reality, accessed in August, 2020.

IHMA, 2020, https://www.ihma.org/history.aspx, accessed in August, 2020.

Jurrien, Ils, Microsoft HoloLens Mixed Reality bril nu te koop in Nederland, 2017, https:// nl.letsgodigital.org/virtual-reality-vr/microsoft-hololens/, accessed in August, 2020

Lynch, Patrick, The World's First Hologram Table is Here, and Could Be Yours for $\$ 47,000$, 2017, https://www.archdaily.com/878348/ the-worlds-first-hologram-table-is-hereand-could-be-yours-for-47000-dollars, accessed in August, 2020.

Newton, Sidney and Lowe, Russell, The Situation Engine: Experience-Based Safety Training, https://ccsbestpractice.org.uk/entries/ the-situation-engine-experience-based-safety-training, accessed in Augutst, 2020.

Sampera, Ernest, 2019, Why Virtual Reality Has Created Data Storage Concerns, https:// www.vxchnge.com/blog/virtual-reality-data-storage-concern,

Sawim co, Your location in the 4th Industrial Design, 2019, https://blog.sawim.com/transferand-localize-technology-from-the-world-toyour-company-and-industry/, accessed in August, 2020.
Tepe, T., Kaleci, D., Tuzun, H. 2018. "Virtual Reality Applications inEducation”. Springer International Publishing AG.

Teklemariam, H., Kakati, V., Kumar, A. 2014. "Application of VR Technology in Design Education". Intertional Conferfnce On Engineering and Product Design Education 4\&5 September.

Tian lo, T., Schnabel, M. 2018. “ Virtual \& Augmented Studio Environment (VASE) Developing the Virtual Reality Eco-System for Design Studios". d Architectural Design Research in Asia (CAADRIA), Volume 1, 443452.

Velev, D., and Zlateva, P., 2017, "Virtual Reality Challenges in Education and Training", International Journal of Learning and Teaching Vol.(3), No (1),

Wang,Peng., Wang, J., Chi, H., Wang, X., 2018. "A Critical Review of the Use of Virtual Reality in Construction Engineering Education and Training". International Journal of Environmental Research and Public Health. 8 June, 15, 1204.

Williams, J., Orooji, F., Aly, SH. 2019. "Integration of Virtual Reality (VR) in Architectural Design Education: Exploring Student experience". American Society for Engineering Education. Paper ID \#27354.

Zhang, Cheng., Chen, Bing. 2019."Enhancing Learning and Teaching for Architectural Engineering Students uing Virtual Building Design and Construction". Higher Education Studies; Vol. 9, No. 2.

\section{Websites}

Arron Fu, CTO UniPrint.net (2017), https://www. uniprint.net/en/7-types-cloud-computingstructures/, accessed in August, 2020.

Grandt, Chris \& Thompson, Adrew, Revolutionizing school design with virtual reality, https://hmcarchitects.com/news/revolutionizing-school-design-with-virtual-reality/, accessed in August, 2020

Ho, Venessa, Design revolution: Microsoft HoloLens and mixed reality are changing how architects see the world, 2017, https:// news.microsoft.com/transform/design-revolution-microsoft-hololens-mixed-reali- 


\title{
Review Article
}

\section{Trends and Challenges of Virtual Reality in Architectural Design Education}

\author{
Shaimaa Ibrahim AL-Kebsi \\ Ahmed Omar M.S. Mostafa \\ Ms.c Student \\ Associate Professor \\ Department of Architecture and Building Sciences, College of Architecture and Planning, King Saud Uni- \\ versity, Riyadh, Saudi Arabia. \\ arc.sh201@gmail.com,439204405@ksu.edu.sa \\ Ahmedoms@ksu.edu.sa
}

Received 4/5/2020; accepted for publication 3/9/2020

\begin{abstract}
Digital technologies are currently employed in almost every aspect of our lives, and have been interwoven in almost every field of specialization. Despite the wide potentials and capabilities of Virtual Reality (VR) technologies in supporting and enhancing education-related activities, many studies indicate that the application of such technologies in the fields of architectural design education is still limited. The objective of this paper is to explore the most important trends and challenges of VR applications in Architectural Design Education for a better understanding the capabilities and limitations of such technologies in supporting educational specialists to explore ways and means to maximize the benefit of using such technologies within different Architectural Design educational environments. The paper adopted the inductive approach analyzing recent literature in this field, supported by case-studies. It is concluded that Architectural Design Education needs to cope with the continuous advancements in VR technologies to comply with the expected future market needs of various modern technologies. The paper Summarizes and compiles the findings in the matrix of "Trends and Challenges of Virtual Reality in Architectural Design Education", which could open the way for future studies through which the priorities and relative importance of such trends and challenges can be determined, as applied in various architectural design educational environments.
\end{abstract}

Key words: Virtual Reality, Architectural Design Education, Virtual Environments, Hologram in Architectural Design, Cloud Computing. 